\title{
Pluripotent stem cell energy metabolism: an update
}

\author{
Tara Teslaa ${ }^{1}$ \& Michael A Teitell $1,2,3,4,5,6,7, *$
}

\begin{abstract}
Recent studies link changes in energy metabolism with the fate of pluripotent stem cells (PSCs). Safe use of PSC derivatives in regenerative medicine requires an enhanced understanding and control of factors that optimize in vitro reprogramming and differentiation protocols. Relative shifts in metabolism from naïve through "primed" pluripotent states to lineage-directed differentiation place variable demands on mitochondrial biogenesis and function for cell types with distinct energetic and biosynthetic requirements. In this context, mitochondrial respiration, network dynamics, TCA cycle function, and turnover all have the potential to influence reprogramming and differentiation outcomes. Shifts in cellular metabolism affect enzymes that control epigenetic configuration, which impacts chromatin reorganization and gene expression changes during reprogramming and differentiation. Induced PSCs (iPSCs) may have utility for modeling metabolic diseases caused by mutations in mitochondrial DNA, for which few disease models exist. Here, we explore key features of PSC energy metabolism research in mice and man and the impact this work is starting to have on our understanding of early development, disease modeling, and potential therapeutic applications.
\end{abstract}

Keywords differentiation; epigenetics; metabolism; mitochondria; pluripotency

DOI 10.15252/embj.201490446 | Received 31 October 2014 | Revised 15 November 2014 | Accepted 17 November 2014 | Published online 4 December 2014

The EMBO Journal (2015) 34: 138-153

See the Glossary for abbreviations used in this article.

\section{Introduction}

Energy production in early mammalian development depends upon many factors, including substrate availability, uptake, and $\mathrm{O}_{2}$ tension. All mammalian cells produce ATP by differing proportions of glycolysis and oxidative phosphorylation (OXPHOS), with the balance between these processes at specific developmental stages or states of cellular activation controlled by multiple intra- and extracellular factors. Glycolysis is the enzymatic conversion of glucose to pyruvate, which generates 2 net ATP molecules per molecule of glucose. Cells that depend mainly on glycolysis for ATP production further convert pyruvate to lactate, which is excreted. By contrast, cells in oxygen-rich environments may prefer OXPHOS for more efficient ATP production, which on average nets 34 additional ATP molecules per glucose by oxidizing pyruvate to acetyl-CoA in the mitochondrial tricarboxylic acid (TCA) cycle. During pre-implantation development of early mouse embryos, ATP is produced mainly by OXPHOS from uptake of pyruvate, lactate, amino acids, and triglyceride-derived fatty acids (Brinster \& Troike, 1979; Martin \& Leese, 1995; Jansen et al, 2008; Leese, 2012). This is followed by a shift to a more balanced mixture of glycolysis and OXPHOS with increasing glucose uptake in the low $\mathrm{O}_{2}$ microenvironment of an implanting blastocyst (Leese \& Barton, 1984; Houghton et al, 1996; Zhou et al, 2012). In vitro studies report a similar increase in glucose uptake in early human embryos advancing to the blastocyst stage in a dish (Gardner et al, 2001). Pyruvate and glucose uptake and amino acid turnover are predictors of human blastocyst quality and enhanced viability for in vitro fertilization protocols (Houghton et al, 2002; Brison et al, 2004). In concept, in vivo differences in early mammalian embryo energy metabolism should be replicated in vitro by cells obtained from distinct stages of embryonic development that are maintained in similar culture conditions.

Human embryonic stem cells (hESCs) originate from the blastocyst inner cell mass and hold great clinical potential for cell replacement therapies because of their high proliferative capacity and their ability to differentiate into any cell type in the body (Thomson et al, 1998). However, the clinical use of differentiated hESCs is limited by ethical concerns regarding the method of hESC acquisition and by potential allogeneic immune rejection (Zhao et al, 2011). To help circumvent these issues, mammalian somatic cells can be reprogrammed to induced pluripotent stem cells (iPSCs) through ectopic expression of different combinations of transcription factors, such as the "Yamanaka cocktail" of POU5F1, SOX2, KLF4, and MYC (Takahashi \& Yamanaka, 2006; Takahashi et al, 2007) or by other

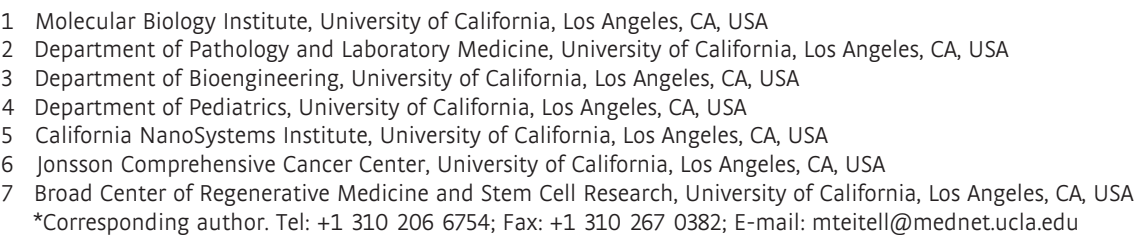




\begin{tabular}{|c|c|c|c|}
\hline \multicolumn{4}{|l|}{ Glossary } \\
\hline $5 \mathrm{hmc}$ & 5-hydroxymethylcytosine & MET & mesenchymal-to-epithelial transition \\
\hline $5 \mathrm{mc}$ & 5-methylcytosine & Mfn1 & mitofusin-1 \\
\hline ADP & adenosine diphosphate & Mfn2 & mitofusin-2 \\
\hline AMD1 & adenosylmethionine decarboxylase 1 & miPSCs & mouse-induced pluripotent stem cells \\
\hline AMP & adenosine monophosphate & МомР & mitochondrial outer membrane permeabilization \\
\hline AMPK & AMP-activated protein kinase & mPSCs & mouse pluripotent stem cells \\
\hline ARNT & aryl hydrocarbon receptor nuclear translocator & mPTP & mitochondrial permeability transition pore \\
\hline ATP & adenosine triphosphate & mtDNA & mitochondrial DNA \\
\hline Cited2 & $\begin{array}{l}\text { CREB-binding protein (CBP)/p300-interacting } \\
\text { transactivator with glutamic acid and aspartic acid tail } 2\end{array}$ & $\begin{array}{l}\text { mTOR } \\
\text { mTORC1 }\end{array}$ & $\begin{array}{l}\text { mammalian target of rapamycin } \\
\text { mammalian target of rapamycin complex } 1\end{array}$ \\
\hline DEPTOR & DEP domain-containing mTOR-interacting protein & mTORC2 & mammalian target of rapamycin complex 2 \\
\hline Drp1 & dynamin-related protein 1 & NAD & nicotinamide adenine dinucleotide \\
\hline EBs & embryoid bodies & NPCs & neural progenitor cells \\
\hline ETC & electron transport chain & NURD & nucleosome remodeling and deacetylase \\
\hline FAD & flavin adenosyl dinucleotide & ОСТ4 & octamer-binding protein 4 \\
\hline FAO & fatty acid oxidation & OPA1 & optic atrophy 1 \\
\hline FBS & fetal bovine serum & OXPHOS & oxidative phosphorylation \\
\hline HAT & histone acetyltransferase & PC & pyruvate carboxylase \\
\hline hESCs & human embryonic stem cells & PDH & pyruvate dehydrogenase \\
\hline HIF1 $\alpha$ & hypoxia-inducible factor $1 \alpha$ & PDK1 & pyruvate dehydrogenase kinase 1 \\
\hline HIF1及 & hypoxia-inducible factor $1 \beta$ & PDK3 & pyruvate dehydrogenase kinase 3 \\
\hline HIF $2 \alpha$ & hypoxia-inducible factor $2 \alpha$ & Phb2 & prohibitin 2 \\
\hline hiPSCs & human-induced pluripotent stem cells & PHD & prolyl hydroxylase \\
\hline hLIF & human leukemia inhibitory factor & POU5F1 & POU class 5 homeobox 1 \\
\hline HMT & histone methyltransferase & PSCs & pluripotent stem cells \\
\hline hPSCs & human pluripotent stem cells & PVHL & von Hippel-Lindau tumor suppressor protein \\
\hline IMS & intermembrane space & PYGL & glycogen phosphorylase liver \\
\hline iPSCs & induced pluripotent stem cells & REX1 & reduced expression 1 \\
\hline JmjC & Jumonji domain-containing & ROS & reactive oxygen species \\
\hline Jph2 & junctophilin 2 & SAM & s-adenosyl methionine \\
\hline KLF4 & Kruppel-like factor 4 & sox2 & SRY (sex-determining region Y)-box 2 \\
\hline LKB1 & liver kinase B1 & TCA cycle & tricarboxylic acid cycle \\
\hline LSD1 & lysine-specific demethylase 1 & TDH & threonine dehydrogenase \\
\hline MEFs & mouse embryonic fibroblasts & Tet1 & ten-eleven translocation \\
\hline mEpisCs & mouse epiblast stem cells & Tsc2 & tuberous sclerosis 2 \\
\hline mESCs & mouse embryonic stem cells & UCP2 & uncoupling protein 2 \\
\hline
\end{tabular}

methods (Yu et al, 2007; Huangfu et al, 2008; Lowry et al, 2008; Ichida et al, 2009; Kim et al, 2009; Lin et al, 2009; Lyssiotis et al, 2009; Zhou et al, 2009a; Jia et al, 2010; Warren et al, 2010; Zhu et al, 2010; Anokye-Danso et al, 2011; Hu et al, 2011; Miyoshi et al, 2011; Bayart \& Cohen-Haguenauer, 2013; Hou et al, 2013; Sommer \& Mostoslavsky, 2013). Both hESCs and human iPSCs (hiPSCs) are markedly glycolytic, secreting abundant lactate, in ambient $(\sim 160 \mathrm{~mm} \mathrm{Hg}) \mathrm{O}_{2}$ (Zhang et al, 2011; Zhou et al, 2012), which differs substantially from the $\sim 40 \mathrm{~mm} \mathrm{Hg} \mathrm{O} \mathrm{O}_{2}$ partial pressure measured for several mammalian reproductive tracts (Fischer \& Bavister, 1993). A similar glycolytic preference in different $\mathrm{O}_{2}$ environs at first pass suggests a pluripotent stage-specific metabolic program that is relatively insensitive to $\mathrm{O}_{2}$ levels in chemically defined or undefined culture media. However, hESCs replicate well in $1-5 \% \quad \mathrm{O}_{2}$ and resist spontaneous differentiation compared to culture in $21 \% \mathrm{O}_{2}$, suggesting that $\mathrm{O}_{2}$ levels influence the factors that maintain pluripotency (Ezashi et al, 2005). Somatic cell reprogramming to hiPSCs or mouse iPSCs (miPSCs) requires a shift from mainly OXPHOS to mainly glycolytic metabolism and high levels of lactate production (Yoshida et al, 2009; Zhou et al, 2012). iPSC production efficiency is enhanced by performing reprogramming in hypoxia or inducing a shift to glycolysis during this process, indicating a role for metabolism in controlling and not just passively responding to de-differentiation (Yoshida et al, 2009; Zhu et al,
2010; Jung et al, 2013). In fact, a shift to glycolysis may occur early in reprogramming before self-renewal and pluripotent gene expression (Folmes Clifford et al, 2011; Mathieu et al, 2014; Prigione et al, 2014). Interestingly, glycolysis-skewed pluripotent stem cells (PSCs), which include ESCs and iPSCs, resemble many cancer cell types that revert to "Warburg metabolism" (aka "aerobic glycolysis”) upon malignant transformation and coupled cellular de-differentiation (Warburg, 1956; Christofk et al, 2008; Figueroa et al, 2010; Lu et al, 2012; Ward Patrick \& Thompson Craig, 2012).

OXPHOS is low in hPSCs, which includes both hESCs and hiPSCs, and the mitochondria are perinuclear and less fused into a filamentous network structure with swollen, less mature appearing inner membrane cristae folds than mitochondria in terminally differentiated cell types (Oh et al, 2005; St John et al, 2005, 2006; Houghton, 2006; Suhr et al, 2010; Zeuschner et al, 2010; Folmes Clifford et al, 2011; Zhang et al, 2011). The perinuclear arrangement of mitochondria has also been noted in cleavage stage embryos of several mammalian species including mice and humans and has been suggested as a "stemness" property (Batten et al, 1987; Barnett et al, 1996; Wilding et al, 2001; Squirrell et al, 2003; Lonergan et al, 2006, 2007). Mouse ESCs (mESCs), which like hESCs are obtained from the blastocyst inner cell mass, contain mitochondria that display even less mature morphological and ultrastructural features than hPSCs (Folmes Clifford et al, 2011; Zhou et al, 2012). 
However, hPSCs metabolically resemble developmentally more mature, glycolytic mouse epiblast stem cells (mEpiSCs), obtained from the post-implantation epiblast, instead of mESCs, which show a bivalent metabolism that can switch between glycolysis and OXPHOS on demand (Zhou et al, 2012). This metabolic comparison is consistent with biomarker and functional features of standard laboratory hPSCs that are "primed", or more mature, than naïve, or ground state hPSCs. Naïve hPSCs, similar to mESCs that represent the least mature pluripotent stage, have recently been obtained by hPSC exposure to chemical inhibitor and growth factor cocktails or by transient expression of two transcription factors combined with two chemical inhibitors and human leukemia inhibitory factor (Fig 1) (Gafni et al, 2013; Takashima et al, 2014; Theunissen Thorold et al, 2014; Ware et al, 2014). hPSCs reset to a naïve state through transient ectopic expression of NANOG and KLF4 respire at a higher level than "primed" hPSCs, similar to pre-implantation mouse embryos and naïve mESCs (Fig 1) (Takashima et al, 2014). The regulation of energy metabolism therefore appears intertwined with genetic and epigenetic mechanisms that control PSC maturation state through pathways that require further elucidation.

\section{Metabolic regulation of self-renewal, reprogramming, and differentiation}

Reprogrammed iPSCs maintain an "epigenetic memory” or chromatin signature of the cells from which they were generated that can impact their re-differentiation potential and function (Kim et al, 2010, 2011; Bar-Nur et al, 2011). Changes in cellular metabolism can impact the activity of epigenome-modifying enzymes, as discussed below (Kaelin William \& McKnight Steven, 2013). Therefore, manipulation of culture conditions could erase or generate new epigenetic marks during iPSC reprogramming, PSC differentiation, or steady-state growth that will affect the functional potential of the end resulting cell. For therapeutic utility, identifying specific, reproducible, and chemically defined culture conditions to produce safe and functional differentiated cells from hPSCs, or by transdifferentiation protocols, will be required. Several key cell types targeted for cell replacement therapies have high energy demands, such as cardiomyocytes and neurons. Therapeutic applications will therefore require re-establishment of a cell type-specific, fully functional mitochondrial network to support the energy and other mitochondrial supplied factors for these replacement cell types. Importantly, mitochondrial dysfunction due to impaired nucleus and mitochondrial encoded genes has been linked to $>400$ named human diseases, including multiple neurodegenerative disorders and cancer (Nunnari \& Suomalainen, 2012).

The discovery that hypoxia maintains self-renewal and increases the efficiency of reprogramming to pluripotency has stimulated studies to determine the role of oxygen tension in cell fate determination. A striking difference in mitochondrial morphology between PSCs and their differentiated derivatives has similarly spurred studies to decipher the mechanisms that control cell state-specific mitochondrial structure and function. Adding to this complexity are state-specific levels of cellular metabolites, such as the AMP/ATP ratio and amino acid availabilities, which can impact PSC gene expression and cell function. In the first part of this review, the effect that these components of cellular metabolism have on selfrenewal and differentiation is explored.

\section{Oxygen tension and hypoxia-inducible factors (HIFs)}

Reduced $\mathrm{O}_{2}(1-5 \%)$ can be used for hPSC tissue culture to mimic the hypoxic early embryonic microenvironment in vivo. Transcription factors such as hypoxia-inducible factor $1 \alpha$ (HIF1 $\alpha$ ) and $2 \alpha$ (HIF2 $\alpha$ ) control the genomic response to low $\mathrm{O}_{2}$ tension by promoting the expression of genes such as pyruvate dehydrogenase kinase 1
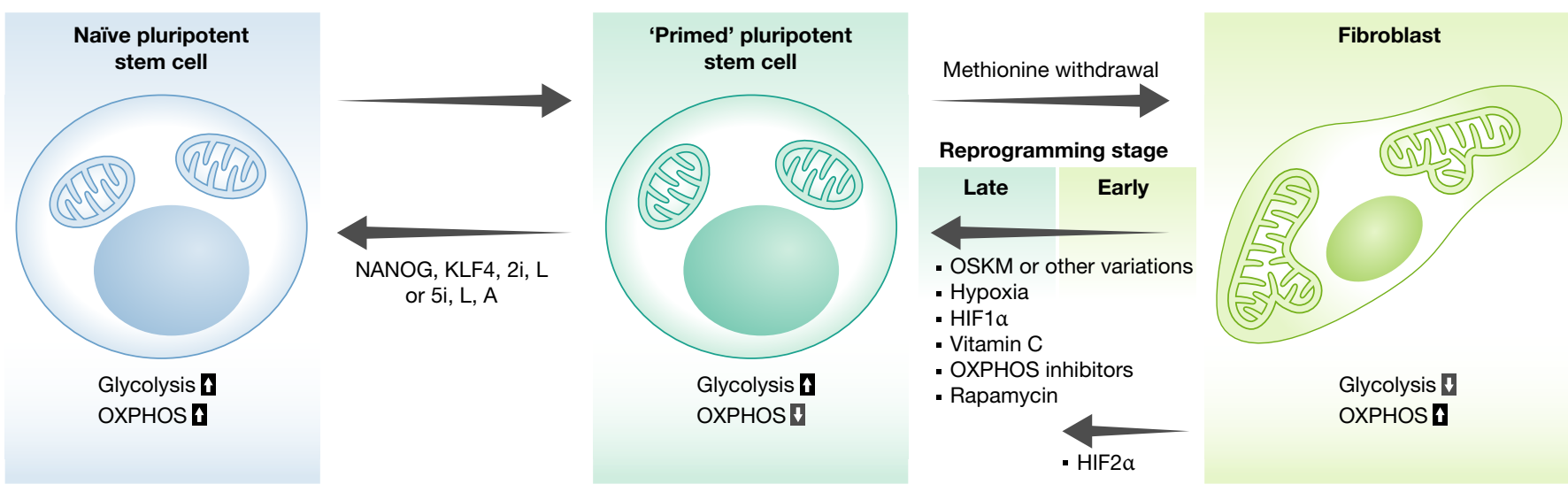

Figure 1. Influence of energy metabolism on pluripotent status.

Naïve human pluripotent stem cells (hPSCS) show an increase in ATP production through oxidative phosphorylation (OXPHOS) compared to more mature, "primed" hPSCs. Primed hPSCS can be converted to the naïve state through ectopic expression of NANOG and KLF4, inhibition of the ERK pathway by two inhibitors (2i), and stimulation with human leukemia inhibitory factor (L) (Takashima et al, 2014). Alternatively, the naïve state can be induced with a cocktail of five inhibitors and growth factors Activin and hLIF (5i/L/A) (Theunissen Thorold et al, 2014). Somatic cells can be reprogrammed with OCT4, SOX2, KLF4, and c-MYC (OSKM). Fibroblasts are more oxidative than primed hPSCs. Factors that activate glycolysis and inhibit OXPHOS promote induced PSC (iPSC) reprogramming. Vitamin C enhances iPSC reprogramming as an antioxidant and as a cofactor for epigenetic enzymes. Rapamycin, an inhibitor of the mTOR pathway, also increases the efficiency of iPSC reprogramming. Withdrawal of methionine from hPSC culture, which is required to maintain DNA and histone methylation, promotes differentiation. 
(PDK1), lactate dehydrogenase A (LDHA), and glycogen phosphorylase liver (PYGL), which encode for key glycolysis regulating enzymes (Greer et al, 2012; Zhou et al, 2012). HIF1 $\alpha$ and HIF2 $\alpha$ are degraded in ambient air $\left(221 \% \mathrm{O}_{2}\right.$ at sea level) by hydroxylation and ubiquitination from $\mathrm{O}_{2}$-dependent prolyl hydroxylases (PHDs) and the von Hippel-Lindau tumor suppressor protein (pVHL), respectively (Maxwell et al, 1999; Ohh et al, 2000; Jaakkola et al, 2001). In hypoxia, HIF $1 \alpha$ and HIF $2 \alpha$ are stabilized and form a heterodimer with the aryl hydrocarbon receptor nuclear translocator (ARNT; aka HIF1 $\beta$ ). HIF heterodimers accumulate in the nucleus and bind to promoters of genes that regulate cellular adaptation to hypoxia, stimulating their transcription (Wang et al, 1995). As noted above, hypoxia inhibits the spontaneous differentiation of hESCs and also increases the efficiency of iPSC reprogramming (Ezashi et al, 2005; Yoshida et al, 2009). HIF2 $\alpha$-dependent transactivation of Oct4 gene expression promotes self-renewal and the maintenance of pluripotency in hypoxia (Niwa et al, 2000; Covello et al, 2006). HIF1 $\alpha$ stabilization promotes a metabolic shift to increased glycolysis and lactate production during the transition from mESCs to mEpiSCs. Ectopic expression of a non-degradable form of HIF1 $\alpha$ in mESCs is sufficient to induce a mEpiSC-like phenotype with a decrease in OXPHOS and an increase in glycolysis, indicating the importance of HIF transcription factors in early embryonic development (Zhou et al, 2012).

Hypoxia causes the re-entry of lineage-committed progenitor cells derived from hESCs back into pluripotency. hESCs transiently induced to lineage non-specific differentiation by fetal bovine serum (FBS) addition instead de-differentiate in $2 \% \mathrm{O}_{2}$, whereas hESCs differentiated with FBS in air $\left(\begin{array}{lll}\sim 21 \% & \mathrm{O}_{2}\end{array}\right)$ proceed ahead. As expected, differentiated hESCs shift their metabolic balance from mainly glycolysis to OXPHOS, whereas de-differentiated hESCs remain glycolytic. De-differentiated hESCs are enriched for HIF1 $\alpha$ and HIF $2 \alpha$ target gene expression, suggesting a role for HIFs in promoting re-entry into the pluripotent state (Mathieu et al, 2013).

HIF $2 \alpha$ is required early in iPSC reprogramming for shifting from mainly OXPHOS to lactate-producing glycolysis, but stabilization of HIF $2 \alpha$ beyond day 12 of reprogramming is detrimental (Fig 1). Ectopic expression of sequence-stabilized HIF1 $\alpha$ and/or HIF2 $\alpha$ is sufficient to impair OXPHOS in fibroblasts (Mathieu et al, 2014). HIF1 $\alpha$ improves iPSC reprogramming efficiency by increasing glycolysis and lactate production through activation of target genes PDK1, pyruvate dehydrogenase kinase 3 (PDK3), and pyruvate kinase isoform M2 (PKM2) (Fig 1) (Mathieu et al, 2014; Prigione et al, 2014). CREB-binding protein (CBP)/p300-interacting transactivator with glutamic acid and aspartic acid tail 2 (Cited2) is a HIF1 $\alpha$ antagonist. Cited 2 is expressed and inhibits HIF1 $\alpha$ during lineage non-specific mESC differentiation, with Cited2 knockout mESCs unable to silence Oct4 or activate differentiation-related genes. shRNA knockdown of HIF1 $\alpha$ in Cited2-deficient mESCs partially rescues this defect in lineage non-specific differentiation (Li et al, 2014).

HIF transactivation also regulates the lineage-specific differentiation of human neural progenitor cells (NPCs) (Xie et al, 2014). Neurons are more oxidative than glial cells (Kasischke et al, 2004; Bélanger et al, 2011). NPCs generated by changing the hPSC culture media to enable the formation of rosette structures can develop into neurons or glia by directed NPC differentiation. NPCs derived from hESC differentiation are mainly glycolytic (Birket et al, 2011), and proteomic comparisons of hESCs at different stages of neural lineage differentiation show differential expression of enzymes that regulate redox homeostasis (Fathi et al, 2014). The differentiation of mixed lineage embryoid bodies (EBs) in $2 \% \mathrm{O}_{2}$ also promotes neurogenesis. Most cells differentiated from hPSC-derived NPCs are neurons with a concomitant small number of glial cells. Remarkably, just shifting the $\mathrm{O}_{2}$ environment during NPC differentiation from 21 to $2 \% \mathrm{O}_{2}$ strongly shifts the culture toward gliogenesis and away from neurogenesis. This effect can be replicated with HIF stabilizing deferoxamine in ambient $\mathrm{O}_{2}$ as well. HIFl $\alpha$ promotes gliogenesis through the inhibition of LIN28a by displacement of MYC on the LIN28 promoter. Remarkably, even a transient low $\mathrm{O}_{2}$ period during NPC differentiation skews the resulting culture strongly toward gliogenesis, suggesting that the $\mathrm{O}_{2}$-sensing machinery induces a lasting effect on NPC differentiation potential (Xie et al, 2014).

\section{Mitochondria and the electron transport chain}

Mammalian cells consume glucose and convert it to pyruvate with ATP production in several enzymatic steps during glycolysis (TeSlaa \& Teitell, 2014). Pyruvate in turn can be converted to lactate by LDH and will be excreted from the cell. Alternatively, pyruvate can enter mitochondria as acetyl-CoA, through the action of pyruvate dehydrogenase $(\mathrm{PDH})$, or as oxaloacetate, via pyruvate carboxylase (PC), to generate $\mathrm{CO}_{2}$ and additional ATP through OXPHOS. Pyruvate that enters the TCA cycle regenerates NADH and $\mathrm{FADH}_{2}$, which subsequently donate electrons to the electron transport chain (ETC) and establish a hydrogen ion gradient, which is used by the $\mathrm{F}_{0} \mathrm{~F}_{1}$ ATP synthase to make ATP from ADP plus inorganic phosphate. ETC activity therefore depends on the ADP/ATP ratio as well as the levels of environmental and internal resources that include TCA cycle carbon substrates and electron acceptors. The levels and functional assemblies of nucleus and mitochondrial DNA (mtDNA) encoded ETC subunits that comprise ETC complexes I through V, excluding nucleus-encoded complex II, and their assemblies into higher order supercomplexes, along with mitochondrial network fusion/fission status, further determines the minimal and maximal respiratory potential of most cells, which remains to be established for PSCs. The complexity of ETC complex regulation has been shown in other systems, including the differential expression of subunits in complex IV and the assembly of complexes I, III, and IV into supercomplexes (Fukuda et al, 2007; Chen et al, 2012b; Ikeda et al, 2013; Lapuente-Brun et al, 2013).

Low-level respiration and activity of the ETC in primed PSCs, including hPSCs and mEpiSCs, may at least partially result from the hypoxic microenvironment in vivo, immediately post-implantation. In addition, the donation of electrons from $\mathrm{NADH}$ and $\mathrm{FADH}_{2}$ to the ETC may result in oxidative stress through formation of reactive oxygen species (ROS). Primed PSCs may limit ROS to prevent damage to proteins, lipids, and importantly DNA within the cell. However, steady-state ROS levels also increase with PSC differentiation and can help drive differentiation at later stages of precursor cell development (Cho et al, 2006; Saretzki et al, 2008). The addition of antioxidants to the culture medium of hiPSCs enhances their genomic stability, consistent with a benefit for maintaining low ROS in PSCs (Luo et al, 2014). Vitamin C, an antioxidant, also enhances the efficiency of iPSC reprogramming (Esteban et al, 2010), 
although vitamin C may also impact reprogramming efficiency through epigenetic mechanisms described below.

ATP and ROS production by OXPHOS is further limited by several mechanisms in hPSCs, such as by the expression of uncoupling protein 2 (UCP2) (Zhang et al, 2011). UCP2 transports four carbon TCA cycle intermediates out of the mitochondria, effectively reducing carbon substrates for use in OXPHOS (Vozza et al, 2014). Also, nuclear genes encoding multiple subunits of cytochrome $\mathrm{C}$ oxidase (complex IV of the ETC), which donates electrons to $\mathrm{O}_{2}$, are expressed at a lower level in mEpiSCs compared to mESCs (Zhou et al, 2012). DMSO-induced differentiation of mPSCs increases ETC complex I and complex IV activities along with mitochondrial biogenesis to support an increase in mitochondrial ATP production (Han et al, 2014). The ETC maintains the mitochondrial inner membrane electrochemical potential, $\Delta \psi$, which is required to prevent mitochondrial outer membrane permeabilization (MOMP) and the release of proapoptotic intermembrane space (IMS) proteins, such as cytochrome $c$, that induce apoptosis (Green \& Kroemer, 2004). When ETC activity is low, $\Delta \psi$ can be additionally supported by the hydrolysis of ATP in the complex V ATP synthase, which results in the translocation of protons from the mitochondrial matrix to the IMS to increase $\Delta \psi$ (Hatefi, 1985). hPSCs have relatively low respiration and ETC activity; therefore, ATP hydrolase activity of the ATP synthase helps to maintain $\Delta \psi$ and sustain cell viability (Zhang et al, 2011). Interestingly, hPSCs maintain a higher $\Delta \psi$ than their differentiated derivatives (Chung et al, 2007; Armstrong et al, 2010; Prigione et al, 2011), which has been proposed to enable rapid metabolic changes during differentiation (Folmes Clifford et al, 2012b; Folmes et al, 2012a) and possibly to maintain a fragmented mitochondrial network (Mattenberger et al, 2003).

iPSC reprogramming of mouse embryonic fibroblasts (MEFs) causes major changes in the expressed proteome in two stages. ETC complex I and complex IV proteins are reduced early during reprogramming, in contrast to components of ETC complexes II, III, and $\mathrm{V}$, which are transiently induced during a second, intermediate reprogramming phase (Hansson et al, 2012). The efficiency and speed of iPSC reprogramming is enhanced when OXPHOS is decreased by inhibition of any of the ETC respiratory complexes, consistent with a required shift toward glycolysis (Fig 1) (Son et al, 2013b).

An increase in OXPHOS capacity is required for proper cardiomyocyte lineage-directed differentiation from PSCs. Cardiomyocyte differentiation induces the expression of nucleus-encoded genes for mtDNA transcription factors, mtDNA replication factors, components of the fatty acid oxidation (FAO) machinery, enzymes of the TCA cycle, and ETC subunits (St John et al, 2005; Chung et al, 2007; Tohyama et al, 2013). Cardiomyocyte-directed differentiation is enhanced by the generation of ROS by NADPH oxidase-like enzymes (Sauer et al, 2000; Crespo et al, 2010). Agonists of peroxisome proliferator-activated receptor $\alpha$ (PPAR $\alpha$ ), a highly expressed nuclear hormone receptor in the heart associated with FAO, promote cardiomyogenesis of mESCs through increasing ROS production (Sharifpanah et al, 2008).

Differences in carbon substrate types can be used to purify metabolically mature mouse cardiomyocytes following differentiation from mPSCs because of key differences in metabolite handling capacity between mouse cardiomyocytes and mPSCs. Fetal cardiomyocytes preferentially consume lactate for the production of ATP (Fisher et al, 1981; Werner \& Sicard, 1987). Therefore, cardiomyocytes derived in vitro from PSCs can utilize lactate in the absence of glucose to produce ATP, whereas mESCs and MEFs are unable to use lactate for ATP production. When cultured in glucosefree media supplemented with lactate, functional mouse cardiomyocytes can be recovered at $\sim 99 \%$ purity (Tohyama et al, 2013).

\section{Mitochondrial dynamics}

The dynamic fusion and fission/fragmentation of an interlacing mitochondrial network enables mixing of mitochondrial contents and the degradation of damaged mitochondria to maintain robust energy and metabolite production (Twig et al, 2008; Westermann, 2012). Mitochondrial network fusion status is a determinant of maximal respiratory capacity (Chen et al, 2005; Yu et al, 2006). PSCs show a punctate, fragmented mitochondrial network that progressively fuses during differentiation, which increases respiratory capacity (Zhang et al, 2011). The GTPase dynamin-related protein 1 (DRP1), which causes mitochondrial fission, can be inhibited to induce a fused mitochondrial network. Pharmacological inhibition of Drp1 to maintain a fused mitochondrial network inhibits iPSC reprogramming (Vazquez-Martin et al, 2012a), although shRNA knockdown of Drp1, also resulting in mitochondrial fusion, did not impair iPSC reprogramming of MEFs (Wang et al, 2014). These paradoxical results could be reconciled by off target effects of the Drp1 inhibitor, insufficient Drp1 shRNA knockdown, or a combination of these or other confounders. Interestingly, reduced expression 1 (REX1) is a zinc finger-containing protein that is required to maintain PSC self-renewal and is repressed during lineage non-specific retinoic acid-induced differentiation. REX1 expression also increases the expression of cyclin B1, which leads to the phosphorylation and activation of DRP1, fission of the mitochondrial network, and increased glycolytic metabolism that is characteristic of PSCs (Son et al, 2013a). The expression pattern of REX1 is concordant with DRP1 activation and mitochondrial fission associated with pluripotency.

Mitochondrial network fusion requires fusion of the outer mitochondrial membrane, mediated by mitofusin-1 and -2 (MFN1 and MFN2), and fusion of the inner mitochondrial membrane, mediated by optic atrophy 1 (OPA1) (Westermann, 2010). Mfn1, Mfn2, and Opal are all required for viable embryonic mouse development (Chen et al, 2003; Alavi et al, 2007). Opa1 also helps to remodel cristae folds of the inner mitochondrial membrane to help mitochondria adapt to changing metabolic demands (Patten et al, 2014). At least five different isoforms of the Opa1 protein exist due to differential splicing and proteolytic cleavage. Prohibitin 2 (Phb2), a nucleusencoded mitochondrial protein, is expressed at high levels in mESCs and promotes expression of the long isoforms of Opa1. Ectopic expression of Phb2 in mESCs inhibits lineage-directed differentiation toward neurons and endoderm and causes mitochondrial swelling (Kowno et al, 2014).

Mfn2 and Opa1 are required for the differentiation of mESCs into beating cardiomyocytes (Kasahara et al, 2013), suggesting that shifting to OXPHOS during cardiomyogenesis also requires mitochondrial network fusion. Mfn2 also tethers mitochondria to the sarcoplasmic reticulum, which is required for $\mathrm{Ca}^{2+}$ signaling and 
energy metabolism in cardiomyocytes (Chen et al, 2012a). Junctophilin 2 (Jph2), which is also part of the junctional membrane complexes that physically link mitochondria with the sarcoplasmic reticulum, is required for proper mitochondria function, $\mathrm{Ca}^{2+}$ homeostasis, and the differentiation of mESCs into cardiomyocytes (Liang et al, 2012). Opening of the mitochondrial permeability transition pore (PTP) enables macromolecular diffusion across the mitochondrial inner membrane, which inhibits ATP production by OXPHOS (Hunter et al, 1976; Kim et al, 2003). Inhibition of the PTP promotes cardiomyocyte differentiation of MPSCs through increasing mitochondrial function (Hom Jennifer et al, 2011; Cho et al, 2014). Interestingly, antioxidant exposure during PTP inhibition synergistically enhances cardiomyogenesis by an unknown mechanism(s) (Cho et al, 2014).

\section{AMPK, mTOR, and autophagy}

Adenosine monophosphate (AMP)-activated protein kinase (AMPK) is a sensor of the AMP/ATP and ADP/ATP energy charge ratio in cells and coordinates the cellular response to changes in energy status. In response to increasing AMP/ATP and ADP/ATP ratios, AMPK becomes phosphorylated by liver kinase B1 (LKB1) to activate catabolic pathways that generate ATP and inhibit anabolic pathways that consume ATP (Hardie et al, 2012). Phosphorylated AMPK inhibits protein translation by inactivating the mammalian target of rapamycin (mTOR) signaling pathway. mTOR exists as two distinct protein complexes, complex 1 (mTORC1) and complex 2 (mTORC2). mTORC1 is an amino acid sensor that regulates protein translation and autophagy. Autophagy is a process that degrades cytoplasmic macromolecules and organelles to provide substrates for energy production, or to remodel cellular functions with changes in differentiation or activation state, and provides a rapid cellular response to changing environmental conditions (Mizushima \& Levine, 2010). Chemical activation of AMPK in mouse and human fibroblasts decreases iPSC reprogramming efficiency, potentially from a failure to fully induce Oct4 gene expression (Vazquez-Martin et al, 2012b). mTOR activity decreases during iPSC reprogramming whereas rapamycin, an inhibitor of the mTOR pathway, enhances iPSC reprogramming of mouse fibroblasts (Fig 1) (Chen et al, 2011; He et al, 2012; Morita et al, 2013). Concordantly, hyperactivation of mTORC1 by knockout of tuberous sclerosis 2 (Tsc2), an upstream kinase inhibitor of mTOR, suppresses iPSC reprogramming (He et al, 2012). Inhibition of the mTOR pathway leads to activation of autophagy and enhances iPSC reprogramming efficiency, possibly from assisted cellular remodeling. Another inducer of autophagy, exposure to spermine, also enhances miPSC reprogramming efficiency (Chen et al, 2011). Moreover, the reprogramming transcription factor Sox2 inhibits mTOR gene expression, which in turn activates autophagy during iPSC reprogramming. Sox2-induced mTOR gene repression occurs by recruitment of the nucleosome remodeling and deacetylase (NuRD) repressor complex to the mTOR gene promoter (Wang et al, 2013a). Although mTOR activation impairs iPSC reprogramming, its inhibition with rapamycin also disrupts expression of OCT4, SOX2, and NANOG genes in hESCs and promotes the expression of endoderm and mesoderm lineage differentiation genes (Zhou et al, 2009b). In contrast, DEP domain-containing mTOR (DEPTOR)-interacting protein, a negative regulator of mTORC1/2, maintains pluripotency for mESCs and hESCs (Agrawal et al, 2014).

The AMPK/mTORC1 pathway regulates mitochondrial biogenesis in somatic cells, and therefore, its role in hPSC differentiation merits further consideration as a mechanism to regulate cell type-specific mitochondrial content and function (Zong et al, 2002; Reznick \& Shulman, 2006; Morita et al, 2013). In addition, AMPK can directly regulate gene expression through histone phosphorylation (Bungard et al, 2010). Studies to determine the mechanism(s) that regulate energy-sensing pathway activation and deactivation during iPSC reprogramming and PSC differentiation may reveal how these changes occur in vivo to control organismal and lineage-specific development.

\section{Other molecular players}

c-Myc is one of the original four reprogramming transcription factors used in iPSC reprogramming of fibroblasts, but it can be removed and/or replaced by Lin28a or other transfactors (Takahashi et al, 2007; Yu et al, 2007; Nakagawa et al, 2008; Wernig et al, 2008). miPSCs reprogrammed with Oct4, Sox2, Klf4, and c-Myc transfactors show an increase in glycolytic metabolism compared to miPSC reprogramming that excludes c-Myc (Folmes et al, 2013b). While the metabolic influence of c-Myc in PSCs has not been further characterized, c-Myc promotes RNA splicing of PKM2 in cancer cells, which activates biosynthetic anabolic pathways (David et al, 2010; Chaneton \& Gottlieb, 2012). c-Myc also has a large role in stimulating glutamine metabolism in lymphocytes and cancer cells (Gao et al, 2009; Le et al, 2012; Liu et al, 2012; Murphy et al, 2013).

LIN28 is an evolutionarily conserved regulator of microRNAs (miRNAs) that can be used for iPSC reprogramming in combination with Oct4, Sox2, and Klf4 (Yu et al, 2007; Viswanathan et al, 2008). Lin28 knockout mice have defects in growth and glucose metabolism (Shinoda et al, 2013). LIN28 expression is regulated by let-7, a miRNA that is also post-transcriptionally repressed by LIN28a in a feedback regulatory loop. Knockdown of let-7 in fibroblasts enhances iPSC reprogramming (Melton et al, 2010). LIN28 preferentially binds to the mRNAs of metabolic enzymes to control their translation, which influences cell growth and survival. Metabolic enzymes targeted by LIN28a in hPSCs include enzymes involved in glycolysis, cholesterol biosynthesis, and mitochondrial metabolism (Peng et al, 2011). Lin28a also enhances the translation of enzymes involved in OXPHOS during the repair of damaged tissues (Shyh-Chang et al, 2013b).

Adenosylmethionine decarboxylase 1 (Amd1) participates in the biosynthesis of polyamines. Polyamines are positively charged metabolites that can bind to acidic sites of macromolecules including nucleic acids, proteins, and phospholipids. Elevated levels of Amd1 are required for self-renewal of mESCs. Additionally, translational inhibition of Amd1 by miR-762 is required for the differentiation of NPCs (Zhang et al, 2012).

\section{Metabolic influence on epigenetics}

Differentiation from and reprogramming to pluripotency, along with transdifferentiation between lineage-specific cell types, involves 
changes in the structure, function, and expression of the nuclear genome. Binding of transcriptional regulators to their target genes before, during, and after these cell fate changing processes depends on dynamic alterations in DNA methylation, histone modifications and variants, chromatin remodeling complex activities, and global and local three-dimensional chromosome topologies (Papp \& Plath, 2013). Cellular metabolism directly influences the epigenetic landscape of a cell by modulating the level and activity of metabolite cofactors and substrates for enzymes that control at least DNA and histone modifications (Kaelin William \& McKnight Steven, 2013). Therefore, cellular metabolite levels and flux help determine cellular fate during iPSC reprogramming and PSC differentiation.

DNA and histone methylation is a major regulator of gene expression and chromatin remodeling (Cedar \& Bergman, 2009). Methyltransferase enzymes that methylate DNA and histones utilize S-adenosyl methionine (SAM) as a methyl donor for transferring methyl groups. Interestingly, SAM levels are elevated in both human and mouse PSCs compared to fibroblasts, but are even higher in hiPSCs when compared to hESCs (Panopoulos et al, 2012; Shyh-Chang et al, 2013a). Additionally, SAM levels increase in the late stages of iPSC reprogramming, indicating coordinate accumulation with increasing pluripotent potential (Shyh-Chang et al, 2013a). Global DNA methylation is also higher in some hiPSC lines when compared to hESCs, suggesting that SAM levels participate in regulating the extent of global DNA methylation (Deng et al, 2009). In mESCs, SAM is generated by uptake of extracellular threonine, which is converted to glycine by threonine dehydrogenase (Tdh) (Fig 2). Therefore, threonine uptake and Tdh activity are required to maintain high levels of SAM in mPSCs. Cleavage of glycine, the product of Tdh, produces SAM by fueling methionine production, which leads to the conversion of methionine plus ATP into SAM via methionine adenosyltransferases (Fig 2) (Shyh-Chang et al, 2013a). mESCs cannot survive in culture medium lacking threonine (Wang et al, 2009) at least partially because histone 3 lysine 4 di- and trimethylation (H3K4me2 and $\mathrm{H} 3 \mathrm{~K} 4 \mathrm{me} 3$ ) is lost in mESCs deprived of threonine, whereas MEFs remain unaffected (Shyh-Chang et al, 2013a). The human TDH gene is a nonfunctional pseudogene due to two splice acceptor mutations and one nonsense mutation. Therefore, threonine cannot be used for SAM production or level regulation in human cells (Wang et al, 2009). hESCs instead depend on the uptake of extracellular methionine for SAM production, with methionine deprivation resulting in a loss of H3K4me3 that predisposes hESCs to differentiation into any of the three embryonic germ layers (Figs 1 and 2). Long-term methionine deprivation leads to cell apoptosis through a p53/p38 mitogen-activated protein kinase (MAPK)-mediated stress signaling response (Shiraki et al, 2014). Therefore, adequate methionine in culture media is required to maintain SAM levels and global DNA and histone methylation. Short-term removal of methionine from hPSC culture media may be used to inhibit enzymatic methyltransferase reactions.

DNA and histone methylations are also susceptible to demethylation reactions. Vitamin C, 2-oxoglutarate ( $\alpha$-ketoglutarate, $\alpha \mathrm{KG}$ ), and $\mathrm{Fe}(\mathrm{II})$ act as cofactors for 2-oxoglutarate(2-OG)dependent dioxygenases, which include ten-eleven translocation (TET) methylcytosine dioxygenases and Jumonji domain-containing (JMJC) histone demethylases (Fig 2). TET methylcytosine dioxygenases oxidize 5-methylcytosine $(5 \mathrm{mC})$ in DNA to form 5-hydroxymethylcytosine $(5 \mathrm{hmc})$, which is an initial modification on the pathway to cytosine demethylation (Delatte et al, 2014). Vitamin C enhances iPSC reprogramming (Fig 1), and Tet1 can replace Oct4 in the iPSC reprogramming cocktail because its expression activates the transcription of Oct4 (Esteban et al, 2010; Gao et al, 2013). Interestingly, the absence of vitamin C impairs hiPSC reprogramming by Tet1, whereas the converse is also observed. With vitamin C, Tet1 inhibits the mesenchymalto-epithelial transition (MET), but in conditions lacking vitamin C, Tet1 promotes reprogramming without activating the MET (Chen et al, 2013). The differences in the role of Tet 1 that depend on the level of vitamin $\mathrm{C}$ in the culture media highlight the importance of optimizing vitamin C levels during iPSC reprogramming, PSC differentiation, and transdifferentiation protocols. Tet dioxygenases can also promote the MET in combination with thymine DNA glycosylase, which enhances iPSC reprogramming (Hu et al, 2014). Moreover, Tet1 can enhance reprogramming by interacting with Nanog to increase expression of key pluripotency-associated target genes (Costa et al, 2013).

The pattern of DNA $5 \mathrm{hmc}$ differs between hESCs and hiPSCs at large hotspots where hiPSCs have been incompletely hydroxymethylated (Wang et al, 2013b). mESCs lose DNA 5hmc when cultured without vitamin $\mathrm{C}$, and addition of vitamin $\mathrm{C}$ leads to a rapid Tet1and Tet2-dependent increase in DNA 5hmc and DNA demethylation (Blaschke et al, 2013; Minor et al, 2013). Resulting vitamin C-induced changes in DNA methylation occur in genomic regions that tend to gain DNA methylation after in vitro culture in contrast to blastocysts in vivo (Blaschke et al, 2013). Consequently, vitamin $\mathrm{C}$ may be an important component of culture media to use to more closely replicate the in vivo environment. Vitamin $\mathrm{C}$ levels can also modulate the activity of the JmjC class of 2-oxoglutarate(2-OG)dependent dioxygenases (Fig 2). JmjC family member proteins Jhdm1a/b enhance iPSC reprogramming in a vitamin C-dependent manner (Wang et al, 2011). Further investigations on the regulation of other JmjC demethylase family member proteins by vitamin C levels may show similar activities.

Surprisingly, the non-essential amino acid L-proline influences the epigenetic state of PSCs. Culturing of mESCs with L-proline causes a mesenchymal-like invasive phenotype while maintaining expression of pluripotency genes. L-proline-treated cells show augmented levels of $\mathrm{H} 3 \mathrm{~K} 36 \mathrm{me} 2$ and $\mathrm{K} 3 \mathrm{~K} 9 \mathrm{me} 3$, which can be reversed by vitamin $\mathrm{C}$ exposure (Comes et al, 2013). Another potential link between cellular metabolism and histone methylation is lysine-specific demethylase 1 (LSD1), which requires flavin adenosine dinucleotide (FAD) for enzymatic activity. Therefore, FAD levels, which also serve as a concentration-dependent cofactor for FAO and respiration, can control the activity of LSD1. LSD1 is required for the maintenance of hESC pluripotency and occupies gene promoters that also bind OCT4 and NANOG transfactors (Adamo et al, 2011).

Histone acetylation is generally associated with gene activation and can often block histone methylation. Sodium butyrate, a histone deacetylase inhibitor, enhances iPSC reprogramming efficiency, emphasizing the importance of dynamic regulation of histone acetylation (Mali et al, 2010; Hou et al, 2013). Sirtuins, a family of NAD-dependent deacetylases, can remove acetyl groups from histones depending on the metabolic state of a cell. The $\mathrm{NAD}^{+} / \mathrm{NADH}$ ratio is significantly higher in hESCs compared to fibroblasts (Salykin et al, 2013), and therefore, the sirtuins may 


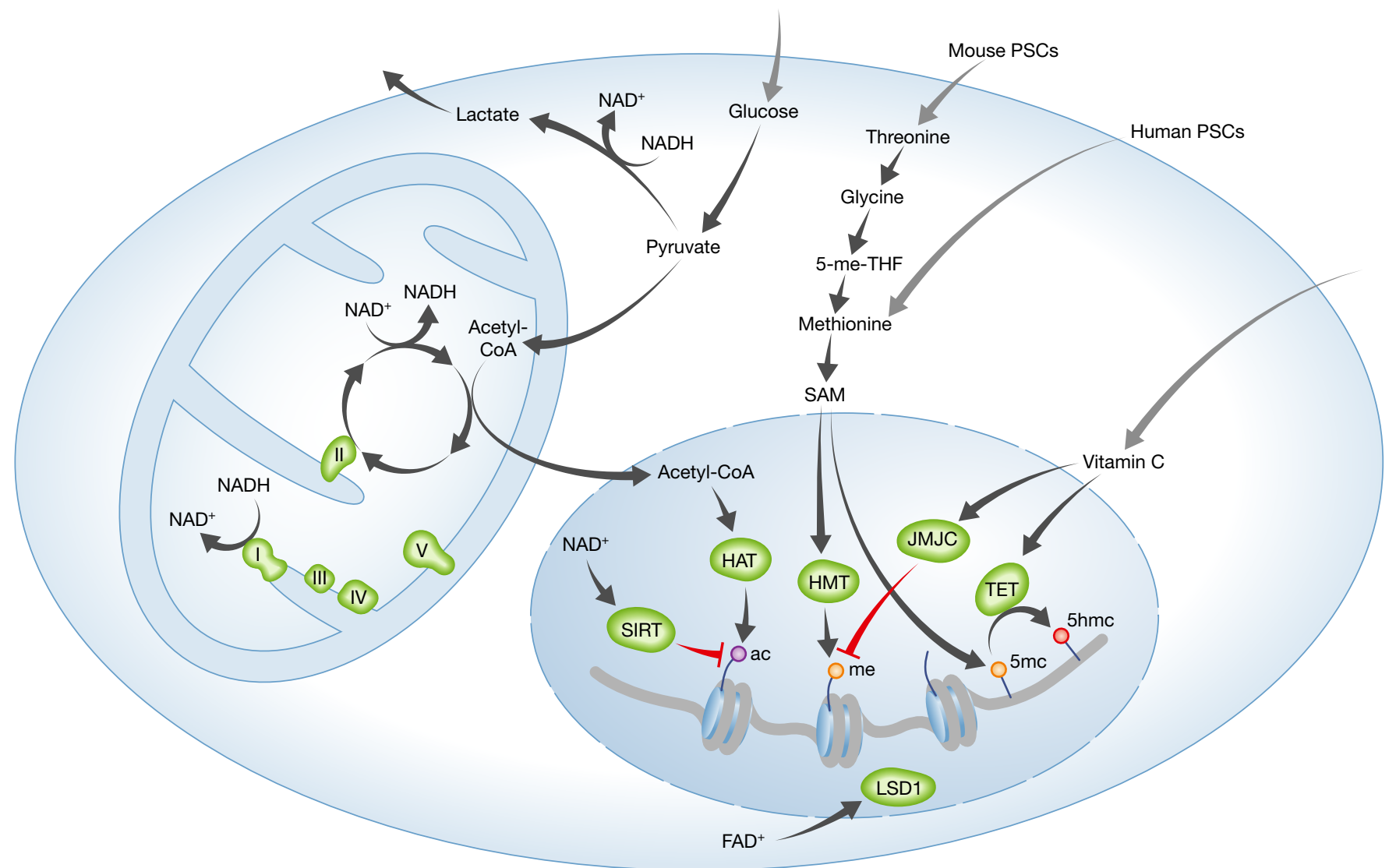

Figure 2. Influence of metabolites on pluripotent stem cell epigenetics.

Intermediate metabolism sets and maintains levels of metabolites that serve as substrates or cofactors for epigenetic modifying enzymes. Uptake of threonine and methionine from the culture media is required to maintain S-adenosylmethionine (SAM) levels in mPSCs and hPSCS, respectively. SAM is a methyl donor for histone methyltransferases (HMT) and DNA methyltransferases (DNMTs). Vitamin C is a cofactor for the JMJC family of demethylases and TET methylcytosine dioxygenases (TET). Acetyl-COA, a TCA cycle intermediate, is an acetyl group donor for histone acetyltransferases (HAT). NAD ${ }^{+}$, generated through glycolysis or by the electron transport chain (ETC), is a cofactor for the sirtuin (SIRT) family of deacetylases.

have differential activity in PSCs versus differentiated cells. Sirt1 is required for genomic stability and telomere elongation of iPSCs (De Bonis Maria et al, 2014). SIRT6 can improve the iPSC reprogramming efficiency of fibroblasts obtained from older patients (Sharma et al, 2013).

How intermediate metabolites from programmed patterns of metabolism and environmental influences regulate epigenomemodifying enzyme activities, such as the sirtuins, requires further study in early development and PSCs. Many studies, especially in cancer, have investigated the role of specific epigenetic enzymes, and their mutant forms, through genetic manipulation. The link between acetyl-CoA levels and protein acetylation has been studied in cancer, but its role has not been investigated in pluripotency, iPSC reprogramming, or hPSC differentiation (Fig 2) (Wellen et al, 2009; Choudhary et al, 2014). In addition to vitamin C, $\alpha$ KG is an important cofactor for dioxygenases. $\alpha \mathrm{KG}$ is a TCA cycle intermediate and can also be produced through conversion from glutamate by aminotransferases involved in other metabolic pathways in the cytosol. In some cancers, the majority of $\alpha \mathrm{KG}$ is produced by phosphoserine aminotransferase 1 (PSAT1) (Possemato et al, 2011).

\section{Mitochondrial disease modeling with hiPSCs}

mtDNA is maternally inherited and encodes genes for 13 protein subunits in 4 of 5 ETC complexes, 2 rRNAs, and 22 tRNAs. Diseasecausing mutations in these mtDNA genes occur in an estimated 1 in 5,000 children and adults (DiMauro \& Schon, 2003; Schaefer et al, 2004). Mammalian cells may contain up to $~ 5-10$ mtDNAs with sequence variations, a mixture state that is termed heteroplasmy (Legros et al, 2004). The heteroplasmy ratio, or the ratio mtDNA carrying a mutant gene to mtDNA carrying the wild-type (WT) gene, varies in cells of each individual, and afflicted patients with the same mtDNA mutation can exhibit a very different range and severity of symptoms (Pickrell Alicia \& Youle Richard, 2013). Cells with the highest energy requirements, such as muscle and brain, are most often affected, but patients may not manifest symptoms until their cells accumulate enough of the disease-causing mutant mtDNA through cell proliferation over time. When the mtDNA mutation burden accumulates to roughly $60-90 \%$ of the total mtDNA present in a cell, OXPHOS may become compromised and symptoms ensue (Mishra \& Chan, 2014). Accurate mouse models of mtDNA mutations are infrequent, and iPSCs have emerged as a potentially good 
model system to study the different cellular manifestations of mutant mtDNA diseases.

The most common mtDNA mutation is a heteroplasmic $3243 \mathrm{~A}>\mathrm{G}$ mutation in the $t R N A-L e u^{(U U R)}$ gene, which can result in two distinct patient phenotypes. Maternally inherited diabetes and deafness (MIDD) is one manifestation of this mutation, whereas the other main manifestation is mitochondrial encephalomyopathy, lactic acidosis, and stroke-like episodes (MELAS syndrome) (Goto et al, 1990; Chae et al, 2004). hiPSCs were successfully generated with heteroplasmic mtDNA $3243 \mathrm{~A}>\mathrm{G}$ of variable mutational loads. While mitochondrial transcripts are unaffected in fibroblasts derived from MELAS patients due to their low energy requirements, there was a decrease in mitochondrial transcripts in hiPSCs with high mutational loads (MELAS-high iPSCs) and in neurons derived from the MELAS-high iPSCs. Respiratory ETC complex activity, however, was decreased in MELAS fibroblasts and not in MELAS-high iPSCs or neurons derived from MELAS-iPSCs (Folmes et al, 2013a; Hämäläinen et al, 2013). Interestingly, MELAS-mutant mtDNA and WT mtDNA had a bimodal segregation pattern at the end of hiPSC reprogramming, resulting in hiPSCs containing either more WT or more mutant mtDNA (Fig 3). Therefore, there is a mtDNA "bottleneck" during hiPSC reprogramming (Cherry et al, 2013), perhaps similar to the mtDNA "bottleneck" that occurs during activated oocyte cleavage divisions in early mammalian development (Shoubridge, 2000; Smith et al, 2002; Cree et al, 2008; Carling et al, 2011), and there is no selection for or against the MELAS mutation (Fig 3) (Hämäläinen et al, 2013). The extent of heteroplasmy in hiPSCs decreases with increasing passage number in vitro (Folmes et al, 2013a).

Fibroblasts from mtDNA "mutator" mice, which carry a mutation in the polymerase gamma (Polg) gene, carry a high mtDNA mutation load due to errors in mtDNA replication (Trifunovic et al, 2004). Mutator iPSCs reprogrammed from mutator MEFs with heavy mtDNA mutational loads proliferate at lower rates and reduced ability to form EBs, teratomas, and chimeric mice. EBs generated from mutator iPSCs are more skewed to glycolytic metabolism than are EBs from WT iPSCs, which could account for their decrease in differentiation potential (Wahlestedt et al, 2014).

Defects in the function of mitochondria may also be caused by mutations in nuclear-encoded genes with roles in mitochondrial energy metabolism, mitochondrial dynamics, mitochondrial transport, apoptosis, or mitophagy. One disease associated with mitochondrial dysfunction by perhaps one or more of these mechanisms is the neurodegenerative disease, Parkinson's disease (PD).

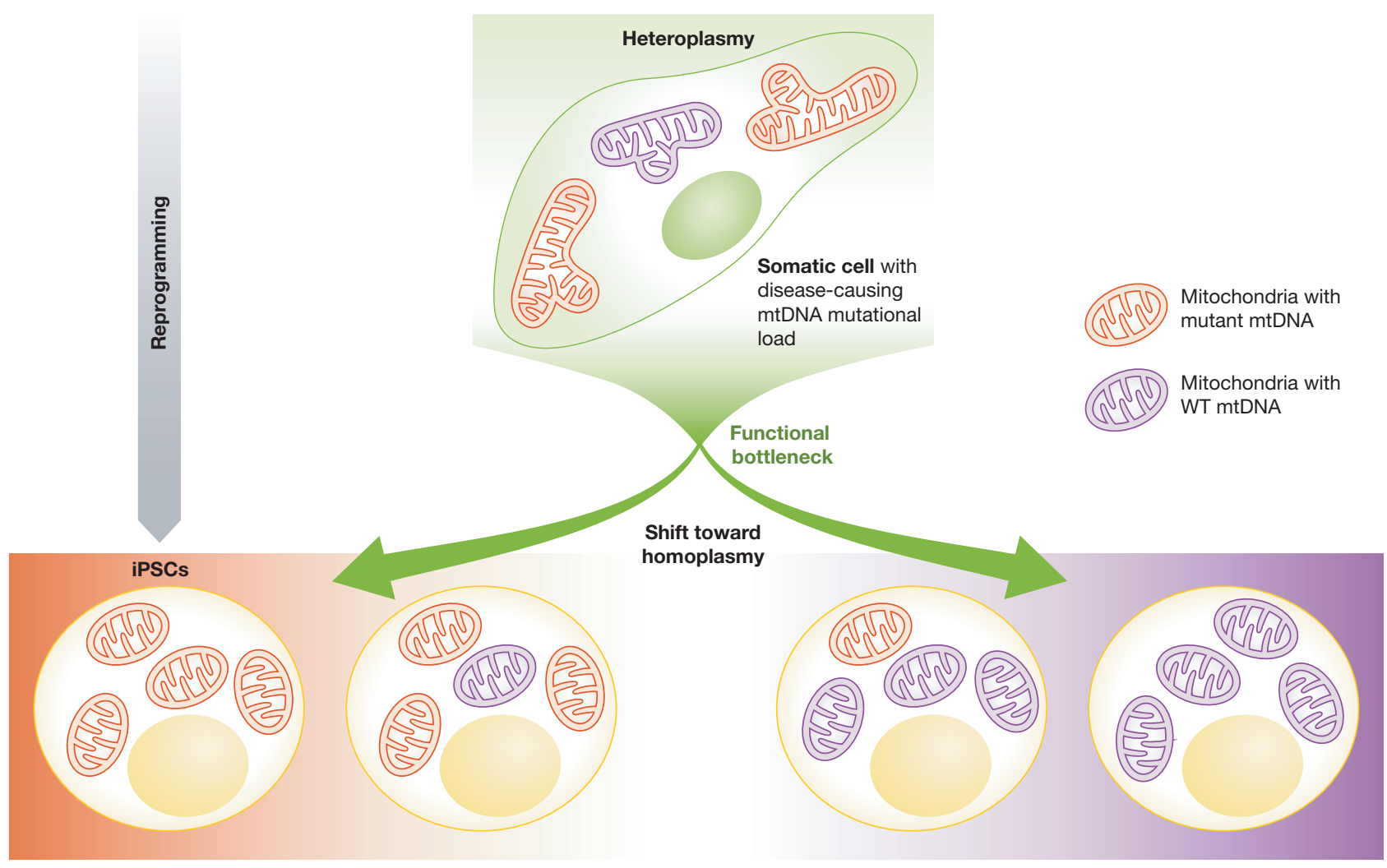


iPSCs have been generated from fibroblasts of PD patients caused by multiple different mutations including parkin (PARK2), PTENinduced putative kinase 1 (PINK1), and leucine-rich kinase 2 (LRRK2) (Seibler et al, 2011; Cooper et al, 2012; Imaizumi et al, 2012). PINK1 and Parkin proteins interact to regulate mitophagy, the process of selectively targeting poorly functioning mitochondria with low $\Delta \psi$ for engulfment by an autophagosome and eventual degradation (Clark et al, 2006; Park et al, 2006). PARK2, an E3 ubiquitin ligase, is recruited to damaged mitochondria in a PINK1-dependent manner to polyubiquitinate mitochondrial outer membrane proteins (Narendra et al, 2008, 2010; Chan et al, 2011). Neurons differentiated from PINK1 mutant iPSCs have abnormalities in mtDNA copy number (Seibler et al, 2011). Additionally, neurons differentiated from both mutant PINK1 and LRRK2 hiPSCs are vulnerable to oxidative stress when exposed to PD-associated toxins. Mitochondria in mutant LRRK2 iPSC-differentiated neurons respire less and are more mobile than those from healthy subjects. Sensitivity of PD iPSC-differentiated neurons to PD-associated toxins is rescued by treatment with either an LRRK2 inhibitor, coenzyme $\mathrm{Q}_{10}$, or rapamycin (Cooper et al, 2012). PARK2 mutant iPSC-differentiated neurons show increased oxidative stress, $\alpha$-synuclein accumulation and Lewy body formation, which are clinical manifestations of PD, providing a model for this aspect of PD pathophysiology (Imaizumi et al, 2012).

\section{Concluding remarks}

Shifts in cellular metabolism accompany shifts in cell identity and facilitate changes in cell function. Applications in regenerative medicine will likely require a fuller understanding of metabolic mechanisms that can alter cellular identity, function, and longevity. Glycolytic metabolism generally accommodates a high rate of biosynthesis and cell proliferation, whereas OXPHOS generates ATP more efficiently for functioning differentiated cells. While progress has been made in understanding how cellular energy metabolism is correlated with pluripotent and differentiated states, most causeand-effect features have not yet been determined. Glycolysis is linked to the primed pluripotent state which is favored in hypoxic environments and by HIF transfactor stabilization. Further work is necessary to identify the transcription factors and signaling pathways that regulate glycolytic flux and overall capacity in PSCs and during induced differentiation. Additionally, the mitochondria in PSCs are rudimentary and the mechanism(s) regulating their maturation or return to immaturity are only starting to be discovered. How the mitochondrial fusion/fission machinery is regulated, what causes changes in mitochondrial localization, what senses and instructs lineage-specific differential mitochondrial mass accumulation and maintenance, and what factors facilitate transitions in metabolism and cell fates remains a significant area of ongoing and future investigations.

PSC metabolism regulates the activities of epigenetic modifying enzymes and therefore influences gene expression patterns, differentiation potential, and functional competence. While the influence of metabolism on SAM levels and global methylation patterns is more heavily studied, the regulation of other key metabolites, such as acetyl-CoA, has not been thoroughly investigated in PSCs and iPSCs. As the connections between energy metabolism and cell fate become unearthed, methods for manipulating PSC metabolism may be harnessed to improve efficiencies and functional outcomes for nuclear reprogramming, PSC differentiation, and transdifferentiation.

\section{Acknowledgements}

TT is supported by a Ruth L. Kirschstein National Research Service Award GM007185. MAT is supported by California Institute for Regenerative Medicine (CIRM) Basic Biology 1 Award RB1-01397, UC Discovery/Nantworks Biotechnology Awards Bio07-10663 and 178517, and US National Institutes of Health (NIH) Awards GM073981, P01GM081621, CA156674, CA90571, GM114188, and CA185189.

\section{Conflict of interest}

The authors declare that they have no conflict of interest.

\section{References}

Adamo A, Sese B, Boue S, Castano J, Paramonov I, Barrero MJ, Belmonte JCI (2011) LSD1 regulates the balance between self-renewal and differentiation in human embryonic stem cells. Nat Cell Biol 13: 652-659

Agrawal P, Reynolds J, Chew S, Lamba DA, Hughes RE (2014) DEPTOR is a stemness factor that regulates pluripotency of embryonic stem cells. J Biol Chem 289: $31818-31826$

Alavi MV, Bette S, Schimpf S, Schuettauf F, Schraermeyer U, Wehrl HF, Ruttiger L, Beck SC, Tonagel F, Pichler BJ, Knipper M, Peters T, Laufs J, Wissinger B (2007) A splice site mutation in the murine Opa1 gene features pathology of autosomal dominant optic atrophy. Brain 130: 1029-1042

Anokye-Danso F, Trivedi Chinmay M, Juhr D, Gupta M, Cui Z, Tian Y, Zhang Y, Yang W, Gruber Peter J, Epstein Jonathan A, Morrisey Edward E (2011) Highly efficient miRNA-mediated reprogramming of mouse and human somatic cells to pluripotency. Cell Stem Cell 8: $376-388$

Armstrong L, Tilgner K, Saretzki G, Atkinson SP, Stojkovic M, Moreno R, Przyborski S, Lako M (2010) Human induced pluripotent stem cell lines show stress defense mechanisms and mitochondrial regulation similar to those of human embryonic stem cells. Stem Cells 28: 661-673

Barnett DK, Kimura J, Bavister BD (1996) Translocation of active mitochondria during hamster preimplantation embryo development studied by confocal laser scanning microscopy. Deu Dyn 205: 64-72

Bar-Nur O, Russ Holger A, Efrat S, Benvenisty N (2011) Epigenetic memory and preferential lineage-specific differentiation in induced pluripotent stem cells derived from human pancreatic islet beta cells. Cell Stem Cell 9: $17-23$

Batten BE, Albertini DF, Ducibella T (1987) Patterns of organelle distribution in mouse embryos during preimplantation development. Am J Anat 178: 204-213

Bayart E, Cohen-Haguenauer O (2013) Technological overview of iPS induction from human adult somatic cells. Curr Gene Ther 13: 73-92

Bélanger M, Allaman I, Magistretti Pierre J (2011) Brain energy metabolism: focus on astrocyte-neuron metabolic cooperation. Cell Metab 14: 724-738

Birket MJ, Orr AL, Gerencser AA, Madden DT, Vitelli C, Swistowski A, Brand MD, Zeng X (2011) A reduction in ATP demand and mitochondrial activity with neural differentiation of human embryonic stem cells. J Cell Sci 124: $348-358$

Blaschke K, Ebata KT, Karimi MM, Zepeda-Martinez JA, Goyal P, Mahapatra S, Tam A, Laird DJ, Hirst M, Rao A, Lorincz MC, Ramalho-Santos M (2013) 
Vitamin C induces tet-dependent DNA demethylation and a blastocyst-like state in ES cells. Nature 500: 222-226

Brinster RL, Troike DE (1979) Requirements for blastocyst development in vitro. J Anim Sci 49(Suppl. 2): 26-34

Brison DR, Houghton FD, Falconer D, Roberts SA, Hawkhead J, Humpherson PG, Lieberman BA, Leese HJ (2004) Identification of viable embryos in IVF by non-invasive measurement of amino acid turnover. Hum Reprod 19: 2319-2324

Bungard D, Fuerth BJ, Zeng P-Y, Faubert B, Maas NL, Viollet B, Carling D, Thompson CB, Jones RG, Berger SL (2010) Signaling kinase AMPK activates stress-promoted transcription via histone $\mathrm{H} 2 \mathrm{~B}$ phosphorylation. Science 329: $1201-1205$

Carling PJ, Cree LM, Chinnery PF (2011) The implications of mitochondrial DNA copy number regulation during embryogenesis. Mitochondrion 11: 686-692

Cedar H, Bergman Y (2009) Linking DNA methylation and histone modification: patterns and paradigms. Nat Reu Genet 10: 295-304

Chae JH, Hwang H, Lim BC, Cheong HI, Hwang YS, Kim KJ (2004) Clinical features of A3243C mitochondrial tRNA mutation. Brain Deu 26: 459-462

Chan NC, Salazar AM, Pham AH, Sweredoski MJ, Kolawa NJ, Graham RLJ, Hess S, Chan DC (2011) Broad activation of the ubiquitin-proteasome system by Parkin is critical for mitophagy. Hum Mol Genet 20: 1726-1737

Chaneton B, Gottlieb E (2012) Rocking cell metabolism: revised functions of the key glycolytic regulator PKM2 in cancer. Trends Biochem Sci 37: $309-316$

Chen H, Detmer SA, Ewald AJ, Griffin EE, Fraser SE, Chan DC (2003) Mitofusins Mfn1 and Mfn2 coordinately regulate mitochondrial fusion and are essential for embryonic development. J Cell Biol 160: 189-200

Chen H, Chomyn A, Chan DC (2005) Disruption of fusion results in mitochondrial heterogeneity and dysfunction. J Biol Chem 280: 26185-26192

Chen T, Shen L, Yu J, Wan H, Guo A, Chen J, Long Y, Zhao J, Pei G (2011) Rapamycin and other longevity-promoting compounds enhance the generation of mouse induced pluripotent stem cells. Aging Cell 10: 908-911

Chen Y, Csordás G, Jowdy C, Schneider TC, Csordás N, Wang W, Liu Y, Kohlhaas M, Meiser M, Bergem S, Nerbonne JM, Dorn GW, Maack C (2012a) Mitofusin 2-containing mitochondrial-reticular microdomains direct rapid cardiomyocyte bioenergetic responses via interorganelle $\mathrm{Ca}^{2+}$ crosstalk. Circ Res 111: 863-875

Chen YC, Taylor EB, Dephoure N, Heo JM, Tonhato A, Papandreou I, Nath N, Denko NC, Gygi SP, Rutter J (2012b) Identification of a protein mediating respiratory supercomplex stability. Cell Metab 15: 348-360

Chen J, Guo L, Zhang L, Wu H, Yang J, Liu H, Wang X, Hu X, Gu T, Zhou Z, Liu J, Liu J, Wu H, Mao S-Q, Mo K, Li Y, Lai K, Qi J, Yao H, Pan G et al (2013) Vitamin $\mathrm{C}$ modulates TET1 function during somatic cell reprogramming. Nat Genet 45: 1504-1509

Cherry AB, Gagne KE, McLoughlin EM, Baccei A, Gorman B, Hartung O, Miller JD, Zhang J, Zon RL, Ince TA, Neufeld EJ, Lerou PH, Fleming MD, Daley GQ, Agarwal S (2013) Induced pluripotent stem cells with a mitochondrial DNA deletion. Stem Cells 31: 1287-1297

Cho YM, Kwon S, Pak YK, Seol HW, Choi YM, Park DJ, Park KS, Lee HK (2006) Dynamic changes in mitochondrial biogenesis and antioxidant enzymes during the spontaneous differentiation of human embryonic stem cells. Biochem Biophys Res Commun 348: 1472-1478

Cho SW, Park JS, Heo HJ, Park SW, Song S, Kim I, Han YM, Yamashita JK, Youm JB, Han J, Koh GY (2014) Dual modulation of the mitochondrial permeability transition pore and redox signaling synergistically promotes cardiomyocyte differentiation from pluripotent stem cells. J Am Heart Assoc 3: e000693

Choudhary C, Weinert BT, Nishida Y, Verdin E, Mann M (2014) The growing landscape of lysine acetylation links metabolism and cell signalling. Nat Reu Mol Cell Biol 15: 536-550

Christofk HR, Vander Heiden MG, Harris MH, Ramanathan A, Gerszten RE, Wei R, Fleming MD, Schreiber SL, Cantley LC (2008) The M2 splice isoform of pyruvate kinase is important for cancer metabolism and tumour growth. Nature 452: $230-233$

Chung S, Dzeja PP, Faustino RS, Perez-Terzic C, Behfar A, Terzic A (2007) Mitochondrial oxidative metabolism is required for the cardiac differentiation of stem cells. Nat Clin Pract Cardiouasc Med 4: S60-S67

Clark IE, Dodson MW, Jiang C, Cao JH, Huh JR, Seol JH, Yoo SJ, Hay BA, Guo M (2006) Drosophila pink1 is required for mitochondrial function and interacts genetically with parkin. Nature 441: 1162-1166

Comes S, Gagliardi M, Laprano N, Fico A, Cimmino A, Palamidessi A, De Cesare D, De Falco S, Angelini C, Scita G, Patriarca Eduardo J, Matarazzo Maria R, Minchiotti G (2013) L-proline induces a mesenchymal-like invasive program in embryonic stem cells by remodeling H3K9 and H3K36 methylation. Stem Cell Rep 1: 307-321

Cooper O, Seo H, Andrabi S, Guardia-Laguarta C, Graziotto J, Sundberg M, McLean JR, Carrillo-Reid L, Xie Z, Osborn T, Hargus G, Deleidi M, Lawson T, Bogetofte H, Perez-Torres E, Clark L, Moskowitz C, Mazzulli J, Chen L, Volpicelli-Daley L et al (2012) Pharmacological rescue of mitochondrial deficits in iPSC-derived neural cells from patients with familial Parkinson's disease. Sci Transl Med 4: 141ra190

Costa Y, Ding J, Theunissen TW, Faiola F, Hore TA, Shliaha PV, Fidalgo M, Saunders A, Lawrence M, Dietmann S, Das S, Levasseur DN, Li Z, Xu M, Reik W, Silva JCR, Wang J (2013) NANOG-dependent function of TET1 and TET2 in establishment of pluripotency. Nature 495: 370-374

Covello KL, Kehler J, Yu H, Gordan JD, Arsham AM, Hu C], Labosky PA, Simon MC, Keith B (2006) HIF-2alpha regulates Oct-4: effects of hypoxia on stem cell function, embryonic development, and tumor growth. Genes Deu 20: $557-570$

Cree LM, Samuels DC, de Sousa Lopes SC, Rajasimha HK, Wonnapinij P, Mann JR, Dahl H-HM, Chinnery PF (2008) A reduction of mitochondrial DNA molecules during embryogenesis explains the rapid segregation of genotypes. Nat Genet 40: 249-254

Crespo FL, Sobrado VR, Gomez L, Cervera AM, McCreath KJ (2010) Mitochondrial reactive oxygen species mediate cardiomyocyte formation from embryonic stem cells in high glucose. Stem Cells 28: 1132-1142

David CJ, Chen M, Assanah M, Canoll P, Manley JL (2010) HnRNP proteins controlled by c-Myc deregulate pyruvate kinase mRNA splicing in cancer. Nature 463: $364-368$

De Bonis Maria L, Ortega S, Blasco Maria A (2014) SIRT1 is necessary for proficient telomere elongation and genomic stability of induced pluripotent stem cells. Stem Cell Rep 2: 690-706

Delatte B, Deplus R, Fuks F (2014) Playing TETris with DNA modifications. EMBO J 33: $1198-1211$

Deng J, Shoemaker R, Xie B, Gore A, LeProust EM, Antosiewicz-Bourget J, Egli D, Maherali N, Park I-H, Yu J, Daley GQ, Eggan K, Hochedlinger K, Thomson J, Wang W, Gao Y, Zhang K (2009) Targeted bisulfite sequencing reveals changes in DNA methylation associated with nuclear reprogramming. Nat Biotechnol 27: 353-360

DiMauro S, Schon EA (2003) Mitochondrial respiratory-chain diseases. N Engl J Med 348: $2656-2668$

Esteban MA, Wang T, Qin B, Yang J, Qin D, Cai J, Li W, Weng Z, Chen J, Ni S, Chen K, Li Y, Liu X, Xu J, Zhang S, Li F, He W, Labuda K, Song Y, 
Peterbauer A et al (2010) Vitamin C enhances the generation of mouse and human induced pluripotent stem cells. Cell Stem Cell 6: 71-79

Ezashi T, Das P, Roberts RM (2005) Low 02 tensions and the prevention of differentiation of hES cells. Proc Natl Acad Sci USA 102: $4783-4788$

Fathi A, Hatami M, Vakilian H, Han C-L, Chen Y-J, Baharvand H, Salekdeh CH (2014) Quantitative proteomics analysis highlights the role of redox hemostasis and energy metabolism in human embryonic stem cell differentiation to neural cells. J Proteomics 101: 1-16

Figueroa ME, Abdel-Wahab O, Lu C, Ward PS, Patel J, Shih A, Li Y, Bhagwat N, Vasanthakumar A, Fernandez HF, Tallman MS, Sun Z, Wolniak K, Peeters JK, Liu W, Choe SE, Fantin VR, Paietta E, Löwenberg B, Licht JD et al (2010) Leukemic IDH1 and IDH2 mutations result in a hypermethylation phenotype, disrupt TET2 function, and impair hematopoietic differentiation. Cancer Cell 18: 553-567

Fischer B, Bavister BD (1993) Oxygen tension in the oviduct and uterus of rhesus monkeys, hamsters and rabbits. J Reprod Fertil 99: 673-679

Fisher DJ, Heymann MA, Rudolph AM (1981) Myocardial consumption of oxygen and carbohydrates in newborn sheep. Pediatr Res 15: 843-846

Folmes CD, Nelson TJ, Dzeja PP, Terzic A (2012a) Energy metabolism plasticity enables stemness programs. Ann N Y Acad Sci 1254: 82-89

Folmes CDL, Martinez-Fernandez A, Perales-Clemente E, Li X, McDonald A, Oglesbee D, Hrstka SC, Perez-Terzic C, Terzic A, Nelson TJ (2013a) Disease-causing mitochondrial heteroplasmy segregated within induced pluripotent stem cell clones derived from a patient with MELAS. Stem Cells 31: $1298-1308$

Folmes CL, Martinez-Fernandez A, Faustino R, Yamada S, Perez-Terzic C, Nelson T, Terzic A (2013b) Nuclear reprogramming with c-Myc potentiates glycolytic capacity of derived induced pluripotent stem cells. J Cardiovasc Transl Res 6: 10-21

Folmes Clifford DL, Nelson Timothy J, Martinez-Fernandez A, Arrell DK, Lindor Jelena Z, Dzeja Petras P, Ikeda Y, Perez-Terzic C, Terzic A (2011) Somatic oxidative bioenergetics transitions into pluripotency-dependent glycolysis to facilitate nuclear reprogramming. Cell Metab 14: $264-271$

Folmes Clifford DL, Dzeja Petras P, Nelson Timothy J, Terzic A (2012b) Metabolic plasticity in stem cell homeostasis and differentiation. Cell Stem Cell 11: 596-606

Fukuda R, Zhang H, Kim J-W, Shimoda L, Dang CV, Semenza Gregg L (2007) HIF-1 regulates cytochrome oxidase subunits to optimize efficiency of respiration in hypoxic cells. Cell 129: 111-122

Gafni O, Weinberger L, Mansour AA, Manor YS, Chomsky E, Ben-Yosef D, Kalma Y, Viukov S, Maza I, Zviran A (2013) Derivation of novel human ground state naive pluripotent stem cells. Nature 504: 282-286

Gao P, Tchernyshyov I, Chang T-C, Lee Y-S, Kita K, Ochi T, Zeller KI, De Marzo AM, Van Eyk JE, Mendell JT, Dang CV (2009) C-Myc suppression of miR-23a/b enhances mitochondrial glutaminase expression and glutamine metabolism. Nature 458: 762-765

Gao Y, Chen J, Li K, Wu T, Huang B, Liu W, Kou X, Zhang Y, Huang H, Jiang Y, Yao C, Liu X, Lu Z, Xu Z, Kang L, Chen J, Wang H, Cai T, Gao S (2013) Replacement of Oct4 by Tet1 during iPSC induction reveals an important role of DNA methylation and hydroxymethylation in reprogramming. Cell Stem Cell 12: $453-469$

Gardner DK, Lane M, Stevens J, Schoolcraft WB (2001) Noninvasive assessment of human embryo nutrient consumption as a measure of developmental potential. Fertil Steril 76: 1175-1180

Goto Y-I, Nonaka I, Horai S (1990) A mutation in the tRNALeu(UUR) gene associated with the MELAS subgroup of mitochondrial encephalomyopathies. Nature 348: 651-653
Green DR, Kroemer C (2004) The pathophysiology of mitochondrial cell death. Science 305: 626-629

Greer SN, Metcalf JL, Wang Y, Ohh M (2012) The updated biology of hypoxia-inducible factor. $E M B O$ J 31: 2448-2460

Hämäläinen RH, Manninen T, Koivumäki H, Kislin M, Otonkoski T, Suomalainen A (2013) Tissue- and cell-type-specific manifestations of heteroplasmic mtDNA 3243A>C mutation in human induced pluripotent stem cell-derived disease model. Proc Natl Acad Sci USA 110: E3622-E3630

Han S, Auger C, Thomas SC, Beites CL, Appanna VD (2014) Mitochondrial biogenesis and energy production in differentiating murine stem cells: a functional metabolic study. Cell Reprogram 16: 84-90

Hansson J, Rafiee Mahmoud R, Reiland S, Polo Jose M, Gehring J, Okawa S, Huber W, Hochedlinger K, Krijgsveld J (2012) Highly coordinated proteome dynamics during reprogramming of somatic cells to pluripotency. Cell Rep 2: $1579-1592$

Hardie DG, Ross FA, Hawley SA (2012) AMPK: a nutrient and energy sensor that maintains energy homeostasis. Nat Reu Mol Cell Biol 13: 251-262

Hatefi Y (1985) The mitochondrial electron transport and oxidative phosphorylation system. Annu Reu Biochem 54: 1015-1069

He J, Kang L, Wu T, Zhang J, Wang H, Gao H, Zhang Y, Huang B, Liu W, Kou Z, Zhang H, Gao S (2012) An elaborate regulation of Mammalian target of rapamycin activity is required for somatic cell reprogramming induced by defined transcription factors. Stem Cells Deu 21: 2630-2641

Hom Jennifer R, Quintanilla Rodrigo A, Hoffman David L, de Mesy Bentley Karen L, Molkentin Jeffery D, Sheu S-S, Porter George A Jr (2011) The permeability transition pore controls cardiac mitochondrial maturation and myocyte differentiation. Deu Cell 21: 469-478

Hou P, Li Y, Zhang X, Liu C, Guan J, Li H, Zhao T, Ye J, Yang W, Liu K, Ge J, Xu J, Zhang Q, Zhao Y, Deng H (2013) Pluripotent stem cells induced from mouse somatic cells by small-molecule compounds. Science 341: 651-654

Houghton FD, Thompson JG, Kennedy CJ, Leese HJ (1996) Oxygen consumption and energy metabolism of the early mouse embryo. Mol Reprod Deu 44: 476 - 485

Houghton FD, Hawkhead JA, Humpherson PG, Hogg JE, Balen AH, Rutherford AJ, Leese HJ (2002) Non-invasive amino acid turnover predicts human embryo developmental capacity. Hum Reprod 17: 999-1005

Houghton FD (2006) Energy metabolism of the inner cell mass and trophectoderm of the mouse blastocyst. Differentiation 74: 11-18

Hu K, Yu J, Suknuntha K, Tian S, Montgomery K, Choi KD, Stewart R, Thomson JA, Slukvin II (2011) Efficient generation of transgene-free induced pluripotent stem cells from normal and neoplastic bone marrow and cord blood mononuclear cells. Blood 117: e109-e119

Hu X, Zhang L, Mao S-Q, Li Z, Chen J, Zhang R-R, Wu H-P, Gao J, Guo F, Liu W, Xu G-F, Dai H-Q, Shi Yujiang G, Li X, Hu B, Tang F, Pei D, Xu G-L (2014) Tet and TDG Mediate DNA demethylation essential for mesenchymal-to-epithelial transition in somatic cell reprogramming. Cell Stem Cell 14: 512-522

Huangfu D, Osafune K, Maehr R, Guo W, Eijkelenboom A, Chen S, Muhlestein W, Melton DA (2008) Induction of pluripotent stem cells from primary human fibroblasts with only Oct4 and Sox2. Nat Biotechnol 26: $1269-1275$

Hunter DR, Haworth RA, Southard JH (1976) Relationship between configuration, function, and permeability in calcium-treated mitochondria. J Biol Chem 251: 5069-5077

Ichida JK, Blanchard J, Lam K, Son EY, Chung JE, Egli D, Loh KM, Carter AC, Di Giorgio FP, Koszka K, Huangfu D, Akutsu H, Liu DR, Rubin LL, Eggan K (2009) A small-molecule inhibitor of tgf-Beta signaling replaces sox2 in reprogramming by inducing nanog. Cell Stem Cell 5: 491-503 
Ikeda K, Shiba S, Horie-Inoue K, Shimokata K, Inoue S (2013) A stabilizing factor for mitochondrial respiratory supercomplex assembly regulates energy metabolism in muscle. Nat Commun 4: 2147 (Electronic Journal)

Imaizumi Y, Okada Y, Akamatsu W, Koike M, Kuzumaki N, Hayakawa $\mathrm{H}$, Nihira T, Kobayashi T, Ohyama M, Sato S (2012) Mitochondrial dysfunction associated with increased oxidative stress and $\alpha$-synuclein accumulation in PARK2 iPSC-derived neurons and postmortem brain tissue. Mol Brain 5: 1-13

Jaakkola P, Mole DR, Tian Y-M, Wilson MI, Gielbert J, Gaskell SJ, Kriegsheim AV, Hebestreit HF, Mukherji M, Schofield CJ, Maxwell PH, Pugh CW, Ratcliffe PJ (2001) Targeting of HIF- $\alpha$ to the von Hippel-Lindau ubiquitylation complex by O2-regulated prolyl hydroxylation. Science 292: $468-472$

Jansen S, Pantaleon M, Kaye PL (2008) Characterization and regulation of monocarboxylate cotransporters SIc16a7 and SIc16a3 in preimplantation mouse embryos. Biol Reprod 79: 84-92

Jia F, Wilson KD, Sun N, Gupta DM, Huang M, Li Z, Panetta NJ, Chen ZY, Robbins RC, Kay MA, Longaker MT, Wu JC (2010) A nonviral minicircle vector for deriving human iPS cells. Nat Methods 7: 197-199

Jung D-W, Kim W-H, Williams DR (2013) Reprogram or reboot: small molecule approaches for the production of induced pluripotent stem cells and direct cell reprogramming. ACS Chem Biol 9: 80-95

Kaelin William G Jr, McKnight Steven L (2013) Influence of metabolism on epigenetics and disease. Cell 153: 56-69

Kasahara A, Cipolat S, Chen Y, Dorn GW, Scorrano L (2013) Mitochondrial fusion directs cardiomyocyte differentiation via calcineurin and notch signaling. Science 342: 734-737

Kasischke KA, Vishwasrao HD, Fisher PJ, Zipfel WR, Webb WW (2004) Neural activity triggers neuronal oxidative metabolism followed by astrocytic glycolysis. Science 305: 99-103

Kim J-S, He L, Lemasters JJ (2003) Mitochondrial permeability transition: a common pathway to necrosis and apoptosis. Biochem Biophys Res Commun 304: $463-470$

Kim D, Kim C-H, Moon J-I, Chung Y-C, Chang M-Y, Han B-S, Ko S, Yang E, Cha KY, Lanza R, Kim K-S (2009) Generation of human induced pluripotent stem cells by direct delivery of reprogramming proteins. Cell Stem Cell 4: $472-476$

Kim K, Doi A, Wen B, Ng K, Zhao R, Cahan P, Kim J, Aryee MJ, Ji H, Ehrlich LIR, Yabuuchi A, Takeuchi A, Cunniff KC, Hongguang H, McKinney-Freeman S, Naveiras O, Yoon TJ, Irizarry RA, Jung N, Seita J et al (2010) Epigenetic memory in induced pluripotent stem cells. Nature 467: 285-290

Kim K, Zhao R, Doi A, Ng K, Unternaehrer J, Cahan P, Hongguang H, Loh Y-H, Aryee MJ, Lensch MW, Li H, Collins JJ, Feinberg AP, Daley GQ (2011) Donor cell type can influence the epigenome and differentiation potential of human induced pluripotent stem cells. Nat Biotechnol 29: 1117-1119

Kowno M, Watanabe-Susaki K, Ishimine H, Komazaki S, Enomoto K, Seki Y, Wang YY, Ishigaki Y, Ninomiya N, Noguchi T-a, Kokubu Y, Ohnishi K, Nakajima Y, Kato K, Intoh A, Takada H, Yamakawa N, Wang P-C, Asashima M, Kurisaki A (2014) Prohibitin 2 regulates the proliferation and lineage-specific differentiation of mouse embryonic stem cells in mitochondria. PLOS ONE 9: e81552

Lapuente-Brun E, Moreno-Loshuertos R, Acín-Pérez R, Latorre-Pellicer A, Colás C, Balsa E, Perales-Clemente E, Quirós PM, Calvo E, Rodríguez-Hernández MA, Navas P, Cruz R, Carracedo Á, López-Otín C, Pérez-Martos A, Fernández-Silva P, Fernández-Vizarra E, Enríquez JA (2013) Supercomplex assembly determines electron flux in the mitochondrial electron transport chain. Science 340: 1567-1570
Le A, Lane Andrew N, Hamaker M, Bose S, Gouw A, Barbi J, Tsukamoto T, Rojas Camilio J, Slusher Barbara S, Zhang H, Zimmerman Lisa J, Liebler Daniel C, Slebos Robbert JC, Lorkiewicz Pawel K, Higashi Richard M, Fan Teresa WM, Dang Chi V (2012) Glucose-independent glutamine metabolism via TCA cycling for proliferation and survival in B cells. Cell Metab 15: 110-121

Leese HJ, Barton AM (1984) Pyruvate and glucose uptake by mouse ova and preimplantation embryos. J Reprod Fertil 72: 9-13

Leese HJ (2012) Metabolism of the preimplantation embryo: 40 years on. Reproduction 143: $417-427$

Legros F, Malka F, Frachon P, Lombes A, Rojo M (2004) Organization and dynamics of human mitochondrial DNA. J Cell Sci 117: 2653-2662

Li Q, Hakimi P, Liu X, Yu W-M, Ye F, Fujioka H, Raza S, Shankar E, Tang F, Dunwoodie SL, Danielpour D, Hoppel CL, Ramírez-Bergeron DL, Qu C-K, Hanson RW, Yang Y-C (2014) Cited2, a transcriptional modulator protein, regulates metabolism in murine embryonic stem cells. J Biol Chem 289: $251-263$

Liang X, Mei Y, Huang X, Shen G, Zhu D, Yu Y, Wang J, Lou Y (2012) Junctophilin 2 knockdown interfere with mitochondrium status in ESC-CMs and cardiogenesis of ES cells. J Cell Biochem 113: $2884-2894$

Lin T, Ambasudhan R, Yuan X, Li W, Hilcove S, Abujarour R, Lin X, Hahm HS, Hao E, Hayek A, Ding S (2009) A chemical platform for improved induction of human iPSCs. Nat Meth 6: 805-808

Liu W, Le A, Hancock C, Lane AN, Dang CV, Fan TW-M, Phang JM (2012) Reprogramming of proline and glutamine metabolism contributes to the proliferative and metabolic responses regulated by oncogenic transcription factor c-MYC. Proc Natl Acad Sci USA 109: 8983-8988

Lonergan T, Brenner C, Bavister B (2006) Differentiation-related changes in mitochondrial properties as indicators of stem cell competence. J Cell Physiol 208: 149-153

Lonergan T, Bavister B, Brenner C (2007) Mitochondria in stem cells. Mitochondrion 7: 289-296

Lowry W, Richter L, Yachechko R, Pyle A, Tchieu J, Sridharan R, Clark A, Plath $K$ (2008) Generation of human induced pluripotent stem cells from dermal fibroblasts. Proc Natl Acad Sci USA 105: 2883-2888

Lu C, Ward PS, Kapoor GS, Rohle D, Turcan S, Abdel-Wahab O, Edwards CR, Khanin R, Figueroa ME, Melnick A, Wellen KE, O'Rourke DM, Berger SL, Chan TA, Levine RL, Mellinghoff IK, Thompson CB (2012) IDH mutation impairs histone demethylation and results in a block to cell differentiation. Nature 483: $474-478$

Luo L, Kawakatsu M, Guo C-W, Urata Y, Huang W-J, Ali H, Doi H, Kitajima Y, Tanaka T, Goto S, Ono Y, Xin H-B, Hamano K, Li T-S (2014) Effects of antioxidants on the quality and genomic stability of induced pluripotent stem cells. Sci Rep 4: 3779

Lyssiotis CA, Foreman RK, Staerk J, Garcia M, Mathur D, Markoulaki S, Hanna J, Lairson LL, Charette BD, Bouchez LC, Bollong M, Kunick C, Brinker A, Cho CY, Schultz PG, Jaenisch R (2009) Reprogramming of murine fibroblasts to induced pluripotent stem cells with chemical complementation of Klf4. Proc Natl Acad Sci USA 106: 8912-8917

Mali P, Chou B-K, Yen J, Ye Z, Zou J, Dowey S, Brodsky RA, Ohm JE, Yu W, Baylin SB, Yusa K, Bradley A, Meyers DJ, Mukherjee C, Cole PA, Cheng L (2010) Butyrate greatly enhances derivation of human induced pluripotent stem cells by promoting epigenetic remodeling and the expression of pluripotency-associated genes. Stem Cells 28 : $713-720$

Martin KL, Leese HJ (1995) Role of glucose in mouse preimplantation embryo development. Mol Reprod Deu 40: 436-443 
Mathieu J, Zhang Z, Nelson A, Lamba DA, Reh TA, Ware C, Ruohola-Baker H (2013) Hypoxia induces re-entry of committed cells into pluripotency. Stem Cells 31: 1737-1748

Mathieu J, Zhou W, Xing Y, Sperber H, Ferreccio A, Agoston Z, Kuppusamy Kavitha T, Moon Randall T, Ruohola-Baker H (2014) Hypoxia-inducible factors have distinct and stage-specific roles during reprogramming of human cells to pluripotency. Cell Stem Cell 14: 592-605

Mattenberger Y, James DI, Martinou JC (2003) Fusion of mitochondria in mammalian cells is dependent on the mitochondrial inner membrane potential and independent of microtubules or actin. FEBS Lett 538: 53-59

Maxwell PH, Wiesener MS, Chang G-W, Clifford SC, Vaux EC, Cockman ME, Wykoff CC, Pugh CW, Maher ER, Ratcliffe PJ (1999) The tumour suppressor protein VHL targets hypoxia-inducible factors for oxygen-dependent proteolysis. Nature 399: $271-275$

Melton C, Judson RL, Blelloch R (2010) Opposing microRNA families regulate self-renewal in mouse embryonic stem cells. Nature 463: 621-626

Minor EA, Court BL, Young JI, Wang G (2013) Ascorbate induces ten-eleven translocation (Tet) methylcytosine dioxygenase-mediated generation of 5-hydroxymethylcytosine. J Biol Chem 288: 13669-13674

Mishra P, Chan DC (2014) Mitochondrial dynamics and inheritance during cell division, development and disease. Nat Reu Mol Cell Biol 15: 634-646

Miyoshi N, Ishii H, Nagano H, Haraguchi N, Dewi DL, Kano Y, Nishikawa S, Tanemura M, Mimori K, Tanaka F, Saito T, Nishimura J, Takemasa I, Mizushima T, Ikeda M, Yamamoto H, Sekimoto M, Doki Y, Mori M (2011) Reprogramming of mouse and human cells to pluripotency using mature microRNAs. Cell Stem Cell 8: 633-638

Mizushima N, Levine B (2010) Autophagy in mammalian development and differentiation. Nat Cell Biol 12: 823-830

Morita M, Gravel S-P, Chénard V, Sikström K, Zheng L, Alain T, Gandin V, Avizonis D, Arguello M, Zakaria C, McLaughlan S, Nouet Y, Pause A, Pollak M, Gottlieb E, Larsson O, St-Pierre J, Topisirovic I, Sonenberg N (2013) mTORC1 controls mitochondrial activity and biogenesis through 4E-BP-dependent translational regulation. Cell Metab 18: 698-711

Murphy TA, Dang CV, Young JD (2013) Isotopically nonstationary 13C flux analysis of Myc-induced metabolic reprogramming in B-cells. Metab Eng 15: $206-217$

Nakagawa M, Koyanagi M, Tanabe K, Takahashi K, Ichisaka T, Aoi T, Okita K, Mochiduki Y, Takizawa N, Yamanaka S (2008) Generation of induced pluripotent stem cells without Myc from mouse and human fibroblasts. Nat Biotechnol 26: 101-106

Narendra D, Tanaka A, Suen D-F, Youle RJ (2008) Parkin is recruited selectively to impaired mitochondria and promotes their autophagy. J Cell Biol 183: $795-803$

Narendra DP, Jin SM, Tanaka A, Suen D-F, Gautier CA, Shen J, Cookson MR, Youle RJ (2010) PINK1 is selectively stabilized on impaired mitochondria to activate Parkin. PLOS Biol 8: e1000298.

Niwa H, Miyazaki J-I, Smith AG (2000) Quantitative expression of Oct-3/4 defines differentiation, dedifferentiation or self-renewal of ES cells. Nat Cenet 24: $372-376$

Nunnari J, Suomalainen A (2012) Mitochondria: in sickness and in health. Cell 148: 1145-1159

Oh SK, Kim HS, Ahn HJ, Seol HW, Kim YY, Park YB, Yoon CJ, Kim D-W, Kim SH, Moon SY (2005) Derivation and characterization of new human embryonic stem cell lines: SNUhES1, SNUhES2, and SNUhES3. Stem Cells 23: 211-219

Ohh M, Park CW, Ivan M, Hoffman MA, Kim T-Y, Huang LE, Pavletich N, Chau V, Kaelin WG (2000) Ubiquitination of hypoxia-inducible factor requires direct binding to the [bgr]-domain of the von Hippel-Lindau protein. Nat Cell Biol 2: $423-427$
Panopoulos AD, Yanes O, Ruiz S, Kida YS, Diep D, Tautenhahn R, Herrerias A, Batchelder EM, Plongthongkum N, Lutz M, Berggren WT, Zhang K, Evans RM, Siuzdak G, Belmonte JCI (2012) The metabolome of induced pluripotent stem cells reveals metabolic changes occurring in somatic cell reprogramming. Cell Res 22: 168-177

Papp B, Plath K (2013) Epigenetics of reprogramming to induced pluripotency. Cell 152: 1324-1343

Park J, Lee SB, Lee S, Kim Y, Song S, Kim S, Bae E, Kim J, Shong M, Kim J-M, Chung J (2006) Mitochondrial dysfunction in Drosophila PINK1 mutants is complemented by parkin. Nature 441: 1157-1161

Patten DA, Wong J, Khacho M, Soubannier V, Mailloux RJ, Pilon-Larose K, MacLaurin JG, Park DS, McBride HM, Trinkle-Mulcahy L, Harper M-E, Germain M, Slack RS (2014) OPA1-dependent cristae modulation is essential for cellular adaptation to metabolic demand. EMBO J 33: $2676-2691$.

Peng S, Chen L-L, Lei X-X, Yang L, Lin H, Carmichael GG, Huang Y (2011) Genome-wide studies reveal that lin28 enhances the translation of genes important for growth and survival of human embryonic stem cells. Stem Cells 29: 496-504

Pickrell Alicia M, Youle Richard J (2013) Mitochondrial disease: mtDNA and protein segregation mysteries in iPSCs. Curr Biol 23: R1052-R1054

Possemato R, Marks KM, Shaul YD, Pacold ME, Kim D, Birsoy K, Sethumadhavan S, Woo H-K, Jang HG, Jha AK (2011) Functional genomics reveal that the serine synthesis pathway is essential in breast cancer. Nature 476: $346-350$

Prigione A, Hossini AM, Lichtner B, Serin A, Fauler B, Megges M, Lurz R, Lehrach H, Makrantonaki E, Zouboulis CC, Adjaye J (2011) Mitochondrial-associated cell death mechanisms are reset to an embryonic-like state in aged donor-derived iPS cells harboring chromosomal aberrations. PLOS ONE 6: e27352.

Prigione A, Rohwer N, Hoffmann S, Mlody B, Drews K, Bukowiecki R, Blümlein K, Wanker EE, Ralser M, Cramer T, Adjaye J (2014) HIF1 $\alpha$ modulates cell fate reprogramming through early glycolytic shift and upregulation of PDK1-3 and PKM2. Stem Cells 32: 364-376

Reznick RM, Shulman GI (2006) The role of AMP-activated protein kinase in mitochondrial biogenesis. J Physiol 574: 33-39

Salykin A, Kuzmic P, Kyrylenko O, Musilova J, Glatz Z, Dvorak P, Kyrylenko S (2013) Nonlinear regression models for determination of nicotinamide adenine dinucleotide content in human embryonic stem cells. Stem Cell Reu and Rep 9: $786-793$

Saretzki G, Walter T, Atkinson S, Passos JF, Bareth B, Keith WN, Stewart R, Hoare S, Stojkovic M, Armstrong L, von Zglinicki T, Lako M (2008) Downregulation of multiple stress defense mechanisms during differentiation of human embryonic stem cells. Stem Cells 26: 455-464

Sauer H, Rahimi G, Hescheler J, Wartenberg M (2000) Role of reactive oxygen species and phosphatidylinositol 3-kinase in cardiomyocyte differentiation of embryonic stem cells. FEBS Lett 476: 218-223

Schaefer AM, Taylor RW, Turnbull DM, Chinnery PF (2004) The epidemiology of mitochondrial disorders - past, present and future. Biochim Biophys Acta 1659: $115-120$

Seibler P, Graziotto J, Jeong H, Simunovic F, Klein C, Krainc D (2011) Mitochondrial Parkin recruitment is impaired in neurons derived from mutant PINK1 induced pluripotent stem cells. J Neurosci 31: $5970-5976$

Sharifpanah F, Wartenberg M, Hannig M, Piper H-M, Sauer H (2008) Peroxisome proliferator-activated receptor $\alpha$ agonists enhance cardiomyogenesis of mouse ES cells by utilization of a reactive oxygen species-dependent mechanism. Stem Cells 26: 64-71 
Sharma A, Diecke S, Zhang WY, Lan F, He C, Mordwinkin NM, Chua KF, Wu JC (2013) The role of SIRT6 protein in aging and reprogramming of human induced pluripotent stem cells. J Biol Chem 288: 18439-18447

Shinoda G, Shyh-Chang N, Soysa T, Zhu H, Seligson MT, Shah SP, Abo-Sido N, Yabuuchi A, Hagan JP, Gregory RI (2013) Fetal deficiency of Lin28 programs life-long aberrations in growth and glucose metabolism. Stem Cells 31: 1563-1573

Shiraki N, Shiraki Y, Tsuyama T, Obata F, Miura M, Nagae G, Aburatani H, Kume K, Endo F, Kume S (2014) Methionine metabolism regulates maintenance and differentiation of human pluripotent stem cells. Cell Metab 19: $780-794$

Shoubridge EA (2000) Mitochondrial DNA segregation in the developing embryo. Hum Reprod 15(Suppl 2): 229-234

Shyh-Chang N, Locasale JW, Lyssiotis CA, Zheng Y, Teo RY, Ratanasirintrawoot S, Zhang J, Onder T, Unternaehrer JJ, Zhu H, Asara JM, Daley GQ, Cantley LC (2013a) Influence of threonine metabolism on S-adenosylmethionine and histone methylation. Science 339: 222-226

Shyh-Chang N, Zhu H, Yvanka de Soysa T, Shinoda G, Seligson Marc T, Tsanov Kaloyan M, Nguyen L, Asara John M, Cantley Lewis C, Daley George Q (2013b) Lin28 enhances tissue repair by reprogramming cellular metabolism. Cell 155: 778-792

Smith LC, Bordignon V, Couto MM, Garcia SM, Yamazaki W, Meirelles FV (2002) Mitochondrial genotype segregation and the bottleneck. Reprod Biomed Online 4: $248-255$

Sommer CA, Mostoslavsky G (2013) The evolving field of induced pluripotency: recent progress and future challenges. J Cell Physiol 228: $267-275$

Son MJ, Jeong BR, Kwon Y, Cho YS (2013b) Interference with the mitochondrial bioenergetics fuels reprogramming to pluripotency via facilitation of the glycolytic transition. Int J Biochem Cell Biol 45: $2512-2518$

Son M-Y, Choi H, Han Y-M, Sook Cho Y (2013a) Unveiling the critical role of REX1 in the regulation of human stem cell pluripotency. Stem Cells 31 $2374-2387$

Squirrell JM, Schramm RD, Paprocki AM, Wokosin DL, Bavister BD (2003) Imaging mitochondrial organization in living primate oocytes and embryos using multiphoton microscopy. Microsc Microanal 9: 190-201

St John JC, Ramalho-Santos J, Gray HL, Petrosko P, Rawe VY, Navara CS, Simerly CR, Schatten GP (2005) The expression of mitochondrial DNA transcription factors during early cardiomyocyte in vitro differentiation from human embryonic stem cells. Cloning Stem Cells 7: $141-153$

St John J, Amaral A, Bowles E, Oliveira J, Lloyd R, Freitas M, Gray H, Navara C, Oliveira G, Schatten G, Spikings E, Ramalho-Santos J (2006) The analysis of mitochondria and mitochondrial DNA in human embryonic stem cells. In Human Embryonic Stem Cell Protocols, Turksen K (ed.), Methods Mol Biol 331: $347-374$.

Suhr ST, Chang EA, Tjong J, Alcasid N, Perkins CA, Goissis MD, Ellisman MH, Perez GI, Cibelli JB (2010) Mitochondrial rejuvenation after induced pluripotency. PLOS ONE 5: e14095

Takahashi K, Yamanaka S (2006) Induction of pluripotent stem cells from mouse embryonic and adult fibroblast cultures by defined factors. Cell 126: $663-676$

Takahashi K, Tanabe K, Ohnuki M, Narita M, Ichisaka T, Tomoda K, Yamanaka $S$ (2007) Induction of pluripotent stem cells from adult human fibroblasts by defined factors. Cell 131: $861-872$

Takashima Y, Guo G, Loos R, Nichols J, Ficz G, Krueger F, Oxley D, Santos F, Clarke J, Mansfield W, Reik W, Bertone P, Smith A (2014) Resetting transcription factor control circuitry toward ground-state pluripotency in human. Cell 158: 1254-1269

TeSlaa T, Teitell MA (2014) Techniques to monitor glycolysis. Methods Enzymol 542: $91-114$

Theunissen Thorold W, Powell Benjamin E, Wang H, Mitalipova M, Faddah Dina A, Reddy J, Fan Zi P, Maetzel D, Ganz K, Shi L, Lungjangwa T, Imsoonthornruksa S, Stelzer Y, Rangarajan S, D’Alessio A, Zhang J, Gao Q, Dawlaty Meelad M, Young Richard A, Gray Nathanael $S$ et al (2014) Systematic identification of culture conditions for induction and maintenance of naive human pluripotency. Cell Stem Cell 15: $471-487$

Thomson JA, Itskovitz-Eldor J, Shapiro SS, Waknitz MA, Swiergiel JJ, Marshall VS, Jones JM (1998) Embryonic stem cell lines derived from human blastocysts. Science 282: 1145-1147

Tohyama S, Hattori F, Sano M, Hishiki T, Nagahata Y, Matsuura T, Hashimoto H, Suzuki T, Yamashita H, Satoh Y, Egashira T, Seki T, Muraoka N, Yamakawa H, Ohgino Y, Tanaka T, Yoichi M, Yuasa S, Murata M, Suematsu M et al (2013) Distinct metabolic flow enables large-scale purification of mouse and human pluripotent stem cell-derived cardiomyocytes. Cell Stem Cell 12: 127-137

Trifunovic A, Wredenberg A, Falkenberg M, Spelbrink JN, Rovio AT, Bruder CE, Bohlooly-Y M, Gidlof S, Oldfors A, Wibom R, Tornell J, Jacobs HT, Larsson $\mathrm{N}-\mathrm{G}$ (2004) Premature ageing in mice expressing defective mitochondrial DNA polymerase. Nature 429: 417-423

Twig G, Elorza A, Molina AJ, Mohamed H, Wikstrom JD, Walzer G, Stiles L, Haigh SE, Katz S, Las G (2008) Fission and selective fusion govern mitochondrial segregation and elimination by autophagy. EMBO J 27: $433-446$

Vazquez-Martin A, Cufí S, Corominas-Faja B, Oliveras-Ferraros C, Vellon L, Menendez JA (2012a) Mitochondrial fusion by pharmacological manipulation impedes somatic cell reprogramming to pluripotency: new insight into the role of mitophagy in cell stemness. Aging 4: 393

Vazquez-Martin A, Vellon L, Quiros PM, Cufi S, Ruiz de Galarreta E, Oliveras-Ferraros C, Martin AG, Martin-Castillo B, Lopez-Otin C, Menendez JA (2012b) Activation of AMP-activated protein kinase (AMPK) provides a metabolic barrier to reprogramming somatic cells into stem cells. Cell Cycle 11: 974-989

Viswanathan SR, Daley GQ, Gregory RI (2008) Selective blockade of MicroRNA processing by Lin28. Science 320: $97-100$

Vozza A, Parisi G, De Leonardis F, Lasorsa FM, Castegna A, Amorese D, Marmo R, Calcagnile VM, Palmieri L, Ricquier D, Paradies E, Scarcia P, Palmieri F, Bouillaud F, Fiermonte G (2014) UCP2 transports C4 metabolites out of mitochondria, regulating glucose and glutamine oxidation. Proc Natl Acad Sci USA 111: 960-965

Wahlestedt M, Ameur A, Moraghebi R, Norddahl GL, Sten G, Woods N-B, Bryder D (2014) Somatic cells with a heavy mitochondrial DNA mutational load render induced pluripotent stem cells with distinct differentiation defects. Stem Cells 32: 1173-1182

Wang GL, Jiang BH, Rue EA, Semenza GL (1995) Hypoxia-inducible factor 1 is a basic-helix-loop-helix-PAS heterodimer regulated by cellular $\mathrm{O} 2$ tension. Proc Natl Acad Sci USA 92: 5510-5514

Wang J, Alexander P, Wu L, Hammer R, Cleaver O, McKnight SL (2009) Dependence of mouse embryonic stem cells on threonine catabolism. Science 325: $435-439$

Wang T, Chen K, Zeng X, Yang J, Wu Y, Shi X, Qin B, Zeng L, Esteban Miguel A, Pan G, Pei D (2011) The histone demethylases Jhdm1a/1b enhance somatic cell reprogramming in a vitamin-C-dependent manner. Cell Stem Cell 9: $575-587$ 
Wang S, Xia P, Ye B, Huang G, Liu J, Fan Z (2013a) Transient activation of autophagy via Sox2-mediated suppression of mTOR is an important early step in reprogramming to pluripotency. Cell Stem Cell 13: 617-625

Wang T, Wu H, Li Y, Szulwach KE, Lin L, Li X, Chen IP, Goldlust IS, Chamberlain SJ, Dodd A, Gong H, Ananiev G, Han JW, Yoon Y-S, Katharine Rudd M, Yu M, Song C-X, He C, Chang Q, Warren ST et al (2013b) Subtelomeric hotspots of aberrant 5-hydroxymethylcytosine-mediated epigenetic modifications during reprogramming to pluripotency. Nat Cell Biol 15: 700-711

Wang L, Ye X, Zhao Q, Zhou Z, Dan J, Zhu Y, Chen Q, Liu L (2014) Drp1 is dispensable for mitochondria biogenesis in induction to pluripotency but required for differentiation of embryonic stem cells. Stem Cells Deu 23: $2422-2434$

Warburg O (1956) On the origin of cancer cells. Science 123: 309-314

Ward Patrick S, Thompson Craig B (2012) Metabolic reprogramming: a cancer hallmark even Warburg did not anticipate. Cancer Cell 21: 297-308

Ware CB, Nelson AM, Mecham B, Hesson J, Zhou W, Jonlin EC, Jimenez-Caliani AJ, Deng X, Cavanaugh C, Cook S (2014) Derivation of naïve human embryonic stem cells. Proc Natl Acad Sci USA 111: $4484-4489$

Warren L, Manos PD, Ahfeldt T, Loh Y-H, Li H, Lau F, Ebina W, Mandal PK, Smith ZD, Meissner A, Daley GQ, Brack AS, Collins JJ, Cowan C, Schlaeger TM, Rossi DJ (2010) Highly efficient reprogramming to pluripotency and directed differentiation of human cells with synthetic modified mRNA. Cell Stem Cell 7: 618-630

Wellen KE, Hatzivassiliou G, Sachdeva UM, Bui TV, Cross JR, Thompson CB (2009) ATP-citrate lyase links cellular metabolism to histone acetylation. Science 324: $1076-1080$

Werner JC, Sicard RE (1987) Lactate metabolism of isolated, perfused fetal, and newborn pig hearts. Pediatr Res 22: $552-556$

Wernig M, Meissner A, Cassady JP, Jaenisch R (2008) c-Myc is dispensable for direct reprogramming of mouse fibroblasts. Cell Stem Cell 2: 10-12

Westermann B (2010) Mitochondrial fusion and fission in cell life and death. Nat Reu Mol Cell Biol 11: $872-884$

Westermann B (2012) Bioenergetic role of mitochondrial fusion and fission. Biochim Biophys Acta 1817: 1833-1838

Wilding M, Dale B, Marino M, di Matteo L, Alviggi C, Pisaturo ML, Lombardi L, De Placido G (2001) Mitochondrial aggregation patterns and activity in human oocytes and preimplantation embryos. Hum Reprod 16: 909-917

Xie Y, Zhang J, Lin Y, Gaeta X, Meng X, Wisidagama DRR, Cinkornpumin J, Koehler Carla M, Malone CS, Teitell MA, Lowry WE (2014) Defining the role of oxygen tension in human neural progenitor fate. Stem Cell Rep 3: $1-15$
Yoshida Y, Takahashi K, Okita K, Ichisaka T, Yamanaka S (2009) Hypoxia enhances the generation of induced pluripotent stem cells. Cell Stem Cell 5: $237-241$

Yu T, Robotham JL, Yoon Y (2006) Increased production of reactive oxygen species in hyperglycemic conditions requires dynamic change of mitochondrial morphology. Proc Natl Acad Sci USA 103: 2653-2658

Yu J, Vodyanik MA, Smuga-Otto K, Antosiewicz-Bourget J, Frane JL, Tian S, Nie J, Jonsdottir GA, Ruotti V, Stewart R, Slukvin II , Thomson JA (2007) Induced pluripotent stem cell lines derived from human somatic cells. Science 318: 1917-1920

Zeuschner D, Mildner K, Zaehres H, Scholer HR (2010) Induced pluripotent stem cells at nanoscale. Stem Cells Deu 19: 615-620

Zhang J, Khvorostov I, Hong JS, Oktay Y, Vergnes L, Nuebel E, Wahjudi PN, Setoguchi K, Wang G, Do A, Jung HJ, McCaffery JM, Kurland IJ, Reue K, Lee WNP, Koehler CM, Teitell MA (2011) UCP2 regulates energy metabolism and differentiation potential of human pluripotent stem cells. EMBO J 30 : $4860-4873$

Zhang D, Zhao T, Ang HS, Chong P, Saiki R, Igarashi K, Yang H, Vardy LA (2012) AMD1 is essential for ESC self-renewal and is translationally down-regulated on differentiation to neural precursor cells. Genes Deu 26: $461-473$

Zhao T, Zhang Z-N, Rong Z, Xu Y (2011) Immunogenicity of induced pluripotent stem cells. Nature 474: 212-215

Zhou H, Wu S, Joo JY, Zhu S, Han DW, Lin T, Trauger S, Bien G, Yao S, Zhu Y, Siuzdak G, Schöler HR, Duan L, Ding S (2009a) Generation of induced pluripotent stem cells using recombinant proteins. Cell Stem Cell 4: $381-384$

Zhou J, Su P, Wang L, Chen J, Zimmermann M, Genbacev O, Afonja O, Horne MC, Tanaka T, Duan E, Fisher SJ, Liao J, Chen J, Wang F (2009b) mTOR supports long-term self-renewal and suppresses mesoderm and endoderm activities of human embryonic stem cells. Proc Natl Acad Sci USA 106: $7840-7845$

Zhou W, Choi M, Margineantu D, Margaretha L, Hesson J, Cavanaugh C, Blau CA, Horwitz MS, Hockenbery D, Ware C, Ruohola-Baker H (2012) HIFl $\alpha$ induced switch from bivalent to exclusively glycolytic metabolism during ESC-to-EpiSC/hESC transition. EMBO J 31: 2103-2116

Zhu S, Li W, Zhou H, Wei W, Ambasudhan R, Lin T, Kim J, Zhang K, Ding S (2010) Reprogramming of human primary somatic cells by OCT4 and chemical compounds. Cell Stem Cell 7: 651-655

Zong H, Ren JM, Young LH, Pypaert M, Mu J, Birnbaum MJ, Shulman GI (2002) AMP kinase is required for mitochondrial biogenesis in skeletal muscle in response to chronic energy deprivation. Proc Natl Acad Sci USA 99: $15983-15987$ 